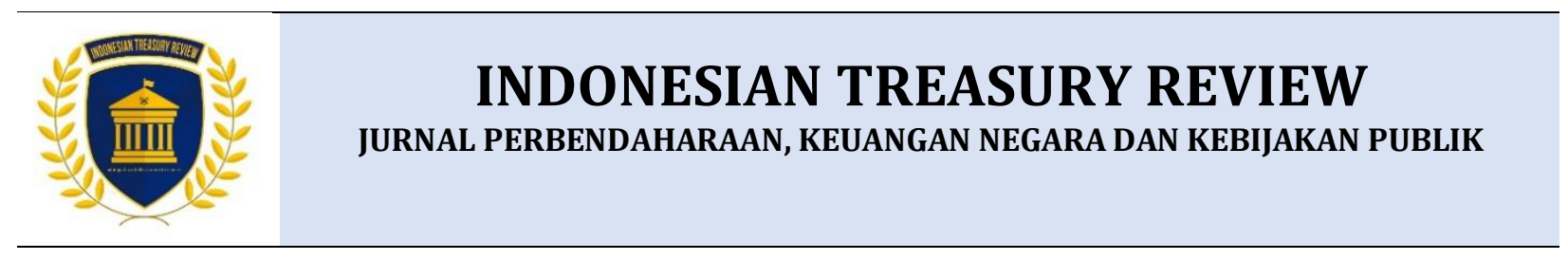

\title{
PARTISIPASI MASYARAKAT DALAM PERENCANAAN APBDES SASAKPANJANG KECAMATAN TAJURHALANG KABUPATEN BOGOR
}

\author{
Heru Cahyono* \\ Balai Diklat Keuangan Makassar, Makassar \\ heruchn@gmail.com \\ Kurniasih Mufidayati \\ Universitas Muhammadiyah Jakarta, Jakarta \\ kmf0219@gmail.com
}

*Alamat Korespondensi:

heruchn@gmail.com

\begin{abstract}
Community participation in the formulation of APBDes is one of the determining factors for villages in achieving the autonomy and prosperity since the law number 6 of 2014 concerning Villages was issued. How Sasakpanjang villagers participate in APBDes formulation is an issue that wants to be clarified through this research. Knowing this can be used to improving policy in the APBDes planning. This study uses the participation ladder from Arnstein. Combined with participatory budgeting theory by Wampler.Method of this study uses a qualitative approach with a descriptive carried out in Sasakpanjang Village, Bogor Regency. The informants in this study were selected purposively. The sample of data sources chosen purposively. Data collection is done through document review and in-depth interviews. Analysis and test of the validity of the data is done through, coding and categorization interview transcripts, interim conclusions, triangulation/crosscheck, and final conclusions. This study has resulted that quality of community participation in Sasakpanjang village at the damping level in the tokenism degree. Communities have begun to have an influence on the APBDes policy, but its nature is still artificial, and has not been able to control the APBDes policy. The inhibiting factors include, weak village government institutions, lack of leadership, and community characteristics. Therefore, village assistance needs to be reoriented.
\end{abstract}

Keywords;

APBDes planning, community participation, inhibiting and supporting factors.

\begin{abstract}
ABSTRAK
Partisipasi masyarakat dalam perumusan kebijakan Anggaran Pendapatan dan Belanja Desa (APBDes) menjadi salah satu faktor yang menentukan bagi desa dalam mencapai kemandirian dan kesejahteraannya. Penelitian ini bertujuan mengetahui bagaimana masyarakat desa Sasakpanjang berpartisipasi dalam perumusan APBDes-nya. Faktor apa yang menghambat partisipasi masyarakat penting untuk diketahui. Penelitian ini merujuk pada teori tangga partisipasi dari Arnstein dan teori penganggaran partisipatif Wampler. Metode penelitian yang digunakan kualitatif deskriptif. Data diperoleh dari telaah dokumen dan indepth interview. Kesimpulan penelitian ini, kualitas partisipasi masyarakat desa Sasakpanjang masih pada level peredaman dalam degree of tokenism. Masyarakat sudah mulai mempunyai pengaruh terhadap kebijakan APBDes, tetapi bersifat artifisial dan belum mampu mengontrol kebijakan APBDes. Faktor-faktor yang menghambat antara lain, lemahnya institusi pemerintahan desa, ketiadaan leadership, budaya masyarakat dan praktik pendampingan desa yang perlu reorientasi karena masih bersifat administratif.
\end{abstract}

Kata Kunci:

Faktor penghambat dan pendukung, partisipasi masyarakat, perencanaan APBDes,

KLASIFIKASI JEL:

R58

CARA MENGUTIP:

Cahyono, H., \& Mufidyati, K. (2021). Partisipasi masyarakat dalam perencanaan apbdes sasakpanjang kecamatan tajurhalang kabupaten bogor. Indonesian Treasury Review: Jurnal Perbendaharaan, Keuangan Negara dan Kebijakan Publik, $6(2), 173-194$ 


\section{PENDAHULUAN}

\section{Latar Belakang}

Langkah penting yang dilakukan dalam mewujudkan tata kelola dan kepemerintahan yang bersih di Indonesia, salah satunya melalui desentralisasi penyelenggaraan pemerintahan. Desentralisasi menjadi alat untuk mengkonsolidasikan kehidupan berdemokrasi dan tata pemerintahan, yang menguntungkan bagi pemerintah maupun masyarakat. Undang-Undang (UU) Nomor 6 Tahun 2014 tentang Desa merupakan wujud upaya membangun good governance melalui desentralisasi yang dilakukan sampai pada level terendah, yaitu desa. Melalui UU ini Negara mengakui dan mendelegasikan kewenangan kepada masyarakat desa untuk mengelola dan menyelenggarakan urusannya secara otonom.

Artikel ini selain menganalisis isu terkini tentang dana desa juga mencoba menganalisis partisipasi masyarakat dan organ-organ desa dalam perencanaan APBDesa. Penelitian telah dilakukan secara mendalam dengan informan-informan yang berkaitan langsung dalam kehidupan pada lokus penelitian.

Penelitian ini hendak menggambarkan partisipasi masyarakat dalam perumusan kebijakan APBDes sebagai bagian dalam mencapai kemandirian dan kesejahteraannya. Penelitian ini juga bertujuan mengetahui bagaimana masyarakat desa Sasakpanjang berpartisipasi dalam perumusan APBDesa-nya. Faktor apa yang menghambat partisipasi masyarakat dalam perumusan kebijakan APBDes menjadi kunci dalam penelitian ini, sekaligus pembeda dengan penelitian sebelumnya. Teori tangga partisipasi dari Arnstein dan teori penganggaran partisipatif Wampler menjadi rujukan dalam analisis.

Metode penelitian yang digunakan kualitatif deskriptif. Pemilihan informan dilakukan secara purposive, sesuai kapasitasnya dalam perencanaan APBDes. Data diperoleh dari telaah dokumen dan indepth interview.

Temuan terkait kualitas partisipasi dan faktorfaktor yang menghambat partisipasi masyarakat dalam perumusan APBDes merupakan bagian dari isu terkini dalam pengelolaan dana desa, meskipun landasan teori yang digunakan sudah cukup lama dan hal yang sama juga sudah dilakukan penelitian pada lokus yang berbeda.

Otonomi desa meliputi aspek self-governing community sesuai hak asal usul dan aspek local selfgovernment yang terkandung dalamnya. UU ini mengakui dan menyerahkan kekuasaan berskala desa, yang meliputi bidang penyelenggaraan pemerintahan, pelaksanaan pembangunan,

\section{PENERAPAN DALAM PRAKTIK}

- Kualitas partisipasi masyarakat pada lokus penelitian masih bersifat semu. Masyarakat memiliki kesempatan berpartisipasi dan cara menyalurkan aspirasi, namun belum berpengaruh signifikan terhadap pengambilan keputusan APBDes.

- Faktor yang menghambat antara lain: lemahnya institusi pemerintahan desa, ketiadaan leadership, budaya masyarakat dan praktek pendampingan yang cenderung bersifat administratif.

- Perlu adanya reformulasi kebijakan yang mampu mendorong penguatan kelembagaan desa dan reorientasi pendampingan desa.

pembinaan kemasyarakatan, dan pemberdayaan masyarakat desa berdasarkan inisiatif masyarakat.

UU ini memberikan kepastian bahwa setiap desa akan memperoleh transfer dana dari pemerintah melalui APBN dan APBD dalam jumlah yang relatif lebih besar dari yang selama ini diterima. Melalui UU ini juga diharapkan masyarakat dapat lebih berpartisipasi dan terlibat dalam proses pembangunan desanya melalui perencanaan, pengelolaan, dan pengawasan pembangunan yang menggunakan dana APBDes.

Salah satu indikator untuk menilai peran masyarakat desa adalah melihat keterlibatannya dalam perencanaan APBDes. Salah satu argumennya adalah bahwa perencanaan APBDes menyangkut pengalokasian dan pendistribusian sumber daya langka desa yang berkaitan dengan pendayagunaan uang yang menjadi hak masyarakat setelah mereka menunaikan kewajiban membayar pajak. (Sukardi, 2009) Penggunaan APBDes seharusnya dapat menjawab masalah kehidupan sehari-hari masyarakat di desa, seperti penyediaan jalan kampung yang tidak becek, kebersihan lingkungan, sarana sanitasi yang memenuhi standar kesehatan dan persoalan-persoalan lokal sejenis yang dekat dengan keseharian masyarakat. Sejauh mana ruang partisipasi tersedia bagi masyarakat desa untuk ikut terlibat mendialogkan persoalan persoalan tersebut, melalui lembaga dan forum yang ada di desa perlu mendapat perhatian. Bagaimana rakyat secara langsung dapat terlibat dalam fungsi perencanaan agar persoalan keseharian seperti tersebut di atas diakomodir di dalam APBDes, perlu mendapat perhatian yang serius.

Forum musyawarah desa mempunyai kedudukan sentral dan strategis sebagai instrumen atau wadah menggalang partisipasi dan aspirasi masyarakat. Musyawarah desa (musdes) yang 
tertuang di dalam UU Desa, merupakan forum musyawarah yang melibatkan berbagai elemen di desa, yang terdiri dari Badan Permusyawaratan Desa (BPD), Kepala Desa/pemerintah desa, dan unsur masyarakat desa untuk membahas hal-hal strategis dalam desa. Menurut ketentuan musyawarah desa diselenggarakan minimal satu kali dalam satu tahun. Penggerak utama untuk menyelenggarakan musdes adalah BPD. Forum musdes diharapkan dapat menjaring aspirasi masyarakat. Butir-butir kesepakatan musdes, yang bersifat prioritas dan strategis akan menjadi bahan penyusunan dokumen perencanaan baik jangka menengah (RPJM Desa) maupun jangka pendek (RKP Desa).

BPD dapat memprakarsai dialog-dialog bersifat public hearing karena salah satu fungsinya untuk menjaring aspirasi masyarakat dan penyambung "lidah rakyat". Oleh karena itu, peran BPD dalam pertemuan atau rapat-rapat formal seperti musyawarah perencanaan pembangunan desa (MUSRENBANGDES) penting untuk diteliti dan ditelaah lebih seksama. Begitu juga dengan hasil kesepakatan dalam MUSRENBANGDES meliputi prioritas atau sasaran apa yang akan dicapai yang perlu diperoleh gambarannya. Kedaulatan desa tertinggi berada di tangan musyawarah desa (Nugroho, 2019). Hanya saja, kedaulatan itu kerap masih terpusat di tangan elite desa. Indikasinya adalah masih belum berubahnya orang-orang yang menghadiri musyawarah desa. Maka observasi dan kajian ini penting dilakukan, untuk mendapatkan gambaran yang lebih detail tentang bagaimana masyarakat desa berpartisipasi dan memiliki prakarsa serta kreativitas dalam perumusan APBDes-nya. Bagaimana BPD dan pemerintah desa memainkan perannya, sehingga kesempatan yang telah diberikan oleh Pemerintah melalui UU Desa tersebut bisa semaksimal mungkin digunakan dalam upaya mencapai kesejahteraan masyarakat desa.

Hal lain yang tidak kalah penting yang melatarbelakangi penelitian ini adalah trend APBDes yang meningkat pasca terbitnya UU Desa, sebagaimana juga terjadi pada Desa Sasakpanjang yang menjadi sebagai lokus riset ini. Peningkatan APBDes masih akan terjadi di masa yang akan datang, seiring dengan kebijakan Pemerintah yang akan terus meningkatkan besarnya dana desa. Peningkatan APBDes tentunya berpotensi meningkatkan kesejahteraan masyarakat desa jika masyarakat terlibat baik dalam proses, perencanaan, pelaksanaan, maupun pengawasan penggunaan anggaran. Melalui keterlibatan warga diharapkan kualitas perencanaan dan pelaksanaan APBDes bisa lebih ditingkatkan.

Berdasarkan observasi awal di Desa Sasakpanjang, terdapat indikasi bahwa kedaulatan masyarakat desa masih terpusat di kalangan elite desa. Musdes sebagai forum tertinggi yang mencerminkan kedaulatan masyarakat, dimana asporasi masyarakat didiskusikan, belum terselenggara. Adapun BPD yang didesain sebagai wadah bagi partisipasi masyarakat untuk guna mempengaruhi dan mengontrol kebijakan pemerintah desa dinilai belum maksimal melakukan tugas dan fungsinya. (Sijabat \& Cahyono, 2016).

Merujuk pada model participatory budgeting yang berhasil diterapkan di Porto Alegre Brazil (Wampler, 2000) dibutuhkan terpenuhinya asumsi dan prasyarat tertentu sebagai faktor keberhasilan penerapan. Mengingat, sering terjadi, partisipasi masyarakat dilakukan sekadar memenuhi prosedur formal saja. Dengan demikian, mengetahui faktor yang mendukung atau menghambat masyarakat untuk berpartisipasi dalam proses perencanaan APBDes adalah hal yang cukup penting. Dengan berbagai uraian persoalan di atas khususnya yang terjadi di Desa Sasakpanjang, menjadi alasan dilakukannya penelitian ini

Formulasi Masalah

Sejalan dengan uraian di atas, dalam kajian ini disusun pertanyaan penelitian sebagai berikut:

1. Bagaimana partisipasi masyarakat Desa Sasakpanjang dalam perencanaan APBDes?

2. Hal-hal apa saja yang mendukung dan menghalangi keikutsertaan masyarakat Desa Sasakpanjang pada proses perencanaan APBDes?

Fokus dari penelitian ini adalah pada partisipasi masyarakat Desa Sasakpanjang, baik langsung maupun tidak langsung pada proses perencanaan dan penganggaran yang bermuara pada tersusunnya APBDes, Desa Sasakpanjang.

Hasil kajian, diharapkan bermanfaat sebagai bahan evaluasi atas partisipasi masyarakat Desa dalam perencanaan APBDes, sekaligus bisa menjadi bahan masukan penyusunan kebijakan tata kelola Dana Desa khususnya pada perencanaan APBDes. Harapan lain dari kajian ini, bisa memberikan nilai tambah bagi pengetahuan dan rujukan penelitianpenelitian berikutnya terkait implementasi UU Desa.

\section{STUDI LITERATUR}

\section{Penelitian Terdahulu}

Irawan (2017) dalam laporan penelitiannya, menyebutkan bahwa kemampuan memobilisasi organisasi pemerintah desa, memberikan pelayanan masyarakat, dan penguatan partisipasi publik dalam pengambilan keputusan tingkat desa, menjadi indikator efektivitas tata kelola pemerintahan desa. Salah satu kesimpulan penelitiannya adalah bahwa elite di desa dan BPD 
sangat berpengaruh terhadap kualitas tata kelola desa.

Raharjo (2017) berdasarkan penelitiannya di Desa Panggungharjo, Sewon, Bantul mengungkapkan bahwa partisipasi masyarakat desa dalam menyusun rencana pembangunan mendekati model citizen power. Model citizen power, mensyaratkan adanya kemitraan, kewenangan dan kendali masyarakat. Dalam konteks desa Panggungharjo, dua syarat telah terpenuhi yaitu kemitraan dan kewenangan, namun masyarakat belum memiliki posisi tawar yang penuh sehingga dapat mempengaruhi setiap kebijakan yang dibuat oleh pemangku kebijakan. Berlangsungnya pembangunan di desa Panggungharjo bukan dikarenakan masyarakat memiliki posisi tawar yang mempengaruhi aparatur pemerintahan desa dalam membuat kebijakan, namun lebih dikarenakan oleh tingkat kepercayaan masyarakat yang tinggi terhadap sosok kepala desa.

Artha (2018) melakukan penelitian di Desa Larolanu dan Desa Pongkalaero menyimpulkan bahwa terdapat perbedaan terkait derajat partisipasi masyarakat dalam pelaksanaan penganggaran dana desa pada desa Pongkalaero dan desa Larolanu. Faktor yang mempengaruhi tinggi rendahnya derajat partisipasi masyarakat pada kedua desa diantaranya disebabkan oleh perbedaan kapasitas masyarakat dalam perencanaan serta pelaksanaan penganggaran program dana desa.

Secara umum hasil riset tersebut, memandang bahwa partisipasi masyarakat merupakan elemen penting dalam tata kelola desa termasuk di dalamnya pengelolaan sumber daya keuangan desa. Partisipasi masyarakat menjadi bagian penting dalam mewujudkan good governance di tingkat desa.

Kajian ini lebih menekankan pada peran serta masyarakat dalam APBDes, mengingat masalahmasalah yang hendak dipecahkan di tingkat desa melalui APBDes mestinya tidak berjarak dengan persoalan keseharian mereka. Apakah masyarakat memiliki kekuatan untuk mengontrol kebijakan pemerintah desa dalam merumuskan APBDes. Kajian ini menggunakan teori tangga partisipasi yang disusun oleh Sherry Arnstein di kombinasikan dengan model aplikatif participatory budgeting yang dikembangkan oleh Brian Wampler.

\section{Desentralisasi dan Otonomi Desa}

UU Desa menjadi titik tolak perubahan signifikan dalam pengaturan tentang desa. Otonomi desa dalam UU tersebut meliputi aspek selfgoverning community sesuai hak asal usul dan aspek local self-government (Irawan, 2017). Artinya, otonomi desa timbul berdasarkan asal usul dan adat istiadatnya. Pemerintah desa memiliki kewenangan tinggi dalam pengembangan desa. Di sisi lain BPD yang menjadi semacam lembaga legislatif di tingkat desa, berfungsi menciptakan mekanisme checks and balances, untuk mewujudkan akuntabilitas layanan yang lebih baik kepada masyarakat des

\section{Partisipasi Masyarakat dan Teori Tangga Partisipasi}

Partisipasi dapat diartikan sebagai bentuk keterlibatan dan keikutsertaan individu dalam suatu wilayah, yang dilakukan secara aktif dan sukarela, pada proses kegiatan kolektif masyarakat (Hadi, 2009). Sebagai suatu proses, partisipasi dapat dipahami sebagai continum (Creighton, 2005). Karena continum, maka sebenarnya ada sejumlah titik tak terbatas pada sepanjang skala, yang oleh Creighton kemudian dibagi menjadi empat kategori utama seperti ditunjukkan oleh lampiran 1.

Kegiatan penyampaian informasi kepada publik yang dikenal juga dengan public relation pada dasarnya adalah komunikasi satu arah kepada masyarakat. Komunikasi lebih bersifat top-down, dimana partisipasi masyarakat sangat minim, hanya sebagai pendengar melalui komunikasi satu arah, misalnya dalam bentuk publikasi melalui media tertentu.

Tingkatan berikutnya yang memerlukan partisipasi masyarakat yang lebih aktif adalah kegiatan yang bersifat dengar pendapat umum (public hearing, listen to the public). Publik dapat menyampaikan komentar atau tanggapan atas rencana tindakan. Dalam praktiknya, mekanisme dengar pendapat sering kali dilaksanakan hanya untuk memenuhi prosedur formal saja, namun secara substansi miskin partisipasi.

Pada kontinum ketiga komunikasi yang lebih melibatkan masyarakat dalam pemecahan masalah, telah terjadi. Karena perbedaan pendapat diakomodir pada level ini, maka dari proses dialog yang dilakukan tidak selalu menghasilkan kesepakatan. Forum curah gagasan dapat dijadikan sebagai wadah untuk berintaraksi satu sama lain dan memahami perbedaan.

Pada level keempat adalah partisipasi yang mampu membangun kesepakatan. Untuk mencapai suatu kesepakatan penuh, memerlukan suatu proses, dengan mencari dan membangun konsensus. Membangun konsensus dapat diartikan sebagai proses pencarian kesepakatan, di mana membangun kesepakatan ini tidak datang tiba-tiba. Hal ini melibatkan itikad baik semua pihak untuk mempertemukan kepentingan semua stakeholders. Manfaat yang diperoleh dari pendekatan kesepakatan adalah jika terbentuk persetujuan yang sejati, yang menjamin lembaga dapat menjalankan pelaksanaan dengan kepercayaan yang wajar. 
Menurut Gaventa \& Valderrama (1999), pemaknaan partisipasi telah bergeser dari pengertian tradisional yang bersifat mikro ke arah yang lebih bersifat makro. Dari partisipasi sebatas pada penerima manfaat (beneficieries) program pembangunan, ke arah partisipasi yang dihubungkan dengan perumusan kebijakan, yang ditujukan pada warga (citizen). Yaitu lebih pada keterlibatan warga dalam pengambilan keputusan atau perumusan kebijakan.

Salah satu aspek partisipasi warga menurut Marilee Karl sebagaimana dikutip oleh Sukardi (2009) adalah derajat partisipasi warga. Derajat partisipasi sering juga disebut sebagai tangga partisipasi. Salah satu teori tangga partisipasi yang banyak menjadi rujukan adalah tangga partisipasi dari Sherry Arnstein dalam tulisannya pada tahun 1969 berjudul A Ladder of Citizen Participation, yang membagi kualitas partisipasi menjadi delapan tingkatan semacam anak tangga (Mufidayati, 2012). Delapan tingkatan partisipasi tersebut, terdiri dari:

1. Tingkatan pertama adalah manipulasi. Partisipasi masyarakat pada tingkatan ini diartikan sebagai ketiadaan komunikasi apalagi dialog.

2. Tingkatan kedua adalah therapy. Pada level ini, sudah ada komunikasi antara warga masyarakat dengan pengambil keputusan namun hanya satu arah, sifatnya masih terbatas sekadar memenuhi prosedur formal. Inisiatif dan pengambilan keputusan sepenuhnya di tangan pemerintah.

3. Tangga ketiga adalah penginformasian (information). Pada level ini komunikasi sudah banyak terjadi tetapi masih bersifat satu arah, belum muncul diskusi dan curah gagasan.

4. Tangga keempat adalah konsultasi. Pada level ini komunikasi telah berjalan dua arah, namun masyarakat belum mampu mendesakkan kepentingannya, sehingga mampu mempengaruhi pengambilan keputusan.

5. Tangga kelima adalah placation. Pada level ini komunikasi sudah berjalan baik dan sudah mulai ada dialog atau rembug bersama antara masyarakat dan pemerintah.

6. Tangga keenam adalah kemitraan (partnership). Pada level ini masyarakat sudah bisa menjadi mitra sejajar pemerintah.

7. Tangga ketujuh adalah delegasi kewenangan (delegated power). Pada level ini pemerintah telah bersedia memberikan kewenangan kepada warga masyarakat untuk berinisiatif mengurus beberapa keperluannya secara mandiri.

8. Tangga kedelapan adalah kontrol warga (citizen control). Pada level ini masyarakat sudah mampu mempengaruhi kebijakan publik secara penuh mulai dari perumusan, implementasi, hingga evaluasi.

Merujuk pada lampiran 9., level partisipasi kesatu dan kedua digolongkan sebagai ketiadaan partisipan (non-participant). Tiga level berikutnya digolongkan sebagai level semu atau sekadar peredaman (tokenism), di mana masyarakat di dengarkan pendapatnya, tetapi pendapat dan pandangan tersebut hanya menjadi bahan pertimbangan oleh pengambil keputusan, sehingga belum menghasilkan perubahan signifikan. Adapun tiga level terakhir digolongkan dalam level kekuasaan masyarakat (citizen power), dimana masyarakat memiliki daya tawar dalam mempengaruhi dan proses pengambilan keputusan.

\section{Partisipasi Dalam Perencanaan Anggaran (Budgeting Participatory)}

Banyak ahli administrasi memandang bahwa partisipasi masyarakat dalam perencanaan anggaran adalah suatu keniscayaan (Orosz, 2002; Beckett \& King, 2002; Mardiyanta, 2013; Sopanah, 2012). Pertanyaan tentang peran masyarakat dalam proses penyusunan anggaran publik adalah pertanyaan penting dan signifikan (Beckett \& King, 2002). Tentunya hal ini juga berlaku pada perencanaan APBDes.

Partisipasi masyarakat dalam perencanaan diperlukan dalam rangka perbaikan tata kelola. Keberhasilan partisipasi masyarakat dalam perencanaan anggaran dapat diukur salah satunya melalui jumlah individu yang terlibat dan efeknya terhadap keputusan. Masyarakat seharusnya menjadi partner setara dalam rapat atau diskusi. Kesuksesan forum musyawarah atau diskusi masyarakat diukur melalui seberapa besar saran atau pendapat warga atau wakilnya dapat merubah outcome sesuai preferensinya. Ukuran sederhananya, apakah keputusan yang dibuat mencerminkan aspirasi mayoritas peserta yang hadir.

Pendidikan dan pengetahuan warga yang baik tentang bagaimana APBDes seharusnya disusun akan mendorong "good will" dari masyarakat untuk terlibat dan berperan aktif di dalamnya. Sosialisasi tentang pentingnya peran serta masyarakat dalam perencanaan APBDes akan mendorong partisipasi yang lebih aktif dari masyarakat. Jika masyarakat merasa aspirasinya ditampung dan diwujudkan dalam APBDes, maka dukungan dan penerimaan masyarakat pada kegiatan yang dilaksanakan oleh kepala desa melalui perangkat-perangkatnya akan menguat.

Participatory Budgeting sebuah model aplikatif dalam penganggaran yang berbasis partisipasi warga diperkenalkan oleh Brian Wampler (2000). Keberhasilan penerapan model pengganggaran tersebut di Kota Porto Alegre Brazil 
mendorong penerapan model serupa di beberapa negara berkembang yang lain.

Participatory Budgeting ala Porto Alegre berlandaskan prinsip musyawarah mufakat, gotong royong, kebersamaan dan kesetaraan. Prinsipprinsip tersebut sebenarnya banyak dijumpai di Indonesia. Lampiran 2 menunjukkan secara sederhana bagaimana siklus tahunan penganggaran yang berbasis partisipasi masyarakat dilakukan di desa-desa di Indonesia.

Model aplikatif participatory budgeting sebenarnya dapat juga dipraktikkan ke dalam proses penganggaran di tingkat desa di Indonesia. Kelembagaan desa yang baru setelah UU Desa terbit, memungkinkan terjadinya pertukaran ide dan gagasan-gagasan seperti pada model anggaran partisipatif tersebut.

\section{Anggaran Pendapatan dan Belanja Desa}

Menurut Sumpeno (2013) APBDes merupakan suatu rencana tahunan keuangan desa yang ditetapkan berdasarkan peraturan desa yang mengandung prakiraan sumber pendapatan dan belanja untuk mendukung kebutuhan program pembangunan desa yang dilaksanakan dalam satu tahun.

APBDes terdiri atas:

\section{Pendapatan Desa}

Terdiri dari semua penerimaan uang melalui rekening kas desa yang merupakan hak desa dalam 1 (satu) tahun anggaran yang tidak perlu dibayar kembali. Secara garis besar pendapatan dalam APBDes dikelompokkan menjadi:
a. Pendapatan Asli Desa;
b. Pendapatan Transfer; dan
c. Pendapatan Lain-lain.

\section{Belanja Desa}

Merujuk pada ketentuan, belanja desa merupakan semua pengeluaran dari rekening kas desa yang merupakan kewajiban desa dalam 1 (satu) tahun anggaran yang tidak akan diperoleh pembayarannya kembali oleh desa. Belanja desa dipergunakan untuk membiayai penyelenggaraan kewenangan desa yang dikelompokkan ke dalam lima bidang, yaitu:

a. bidang penyelenggaraan pemerintahan;

b. bidang pelaksanaan pembangunan;

c. bidang pembinaan kemasyarakatan;

d. bidang pemberdayaan masyarakat; dan

e. bidang penanggulangan bencana, keadaan darurat dan mendesak Desa

\section{Pembiayaan Desa}

Terdiri dari semua penerimaan yang perlu dibayar kembali dan/atau pengeluaran yang akan diterima kembali, baik pada tahun anggaran yang bersangkutan maupun pada tahun tahun anggaran berikutnya. Pembiayaan desa terdiri atas Penerimaan Pembiayaan dan Pengeluaran Pembiayaan yang diklasifikasikan menurut kelompok dan jenis.

\section{Kerangka Berfikir}

Wujud nyata otonomi desa, tercermin pada proses penyusunan perencanaan dan penganggaran desa yang dilakukan secara demokratis (Waskitojati, Handoyo, \& Wuryaningsih, 2016). Artinya dalam proses perencanaan dan penganggaran, pemerintah desa, membuka ruang partisipasi masyarakat dalam berbagai bentuk. Misalnya, pemerintah desa memberikan akses yang luas kepada masyarakat untuk mendapatkan informasi tentang sumber daya anggaran, berapa besarnya, dari mana sumbernya, dan untuk apa saja penggunaannya. Selain itu masyarakat desa diberi kesempatan untuk memberikan masukan dan menyampaikan usulan dalam proses perencanaan desa. Dengan demikian masyarakat di desa dapat berkontribusi dalam menentukan arah pembangunan desa.

Lampiran 3 menggambarkan alur partisipasi masyarakat dalam proses perencanaan APBDes. Partisipasi masyarakat dapat berupa penyampaian usulan atau aspirasi kepada institusi demokrasi di tingkat desa yaitu BPD, kepada kepala desa sebagai pemegang kekuasaan pemerintahan desa atau langsung melalui forum musdes. Aspirasi masyarakat selanjutnya dibahas di forum tertinggi yaitu musdes yang diselenggarakan paling kurang satu kali dalam satu tahun. Melalui forum musdes, elemen-elemen masyarakat di desa seperti tokoh agama, kelompok perempuan, kelompok tani atau profesi lainnya, kelompok pemuda dan unsur pemerintah desa mendiskusikan permasalahanpermasalahan di tingkat desa yang nanti akan diselesaikan dalam bentuk program dan kegiatan yang akan ditampung di APBDes.

Forum musdes diinisiasi oleh BPD dan digunakan sebagai ajang untuk menampung dan mendiskusikan aspirasi masyarakat yang kemudian dirumuskan dalam bentuk kegiatan-kegiatan yang akan dituangkan ke dalam dokumen perencanaan desa tahunan yaitu Rencana Kerja Pemerintah Desa (RKPDes). RKPDes yang telah mendapat pagu definitif dari level pemerintah di atasnya dan telah dibahas dalam forum musdes akan menjadi APBDes dengan formula-formula tertentu sesuai ketentuan.

Lingkup partisipasi masyarakat dalam perencanaan anggaran memiliki cakupan dan dimensi yang luas. Dalam penelitian ini, dimensi partisipasi masyarakat yang digunakan setidaknya meliputi peran, kesempatan, perluasan cara, dan langkah-langkah mengukur keberhasilan 
partisipasi masyarakat (Beckett \& King, 2002), sebagaimana ditunjukkan oleh lampiran 4.

Dari sisi peran, Beckett \& King (2002) mendeskripsikan partisipasi masyarakat meliputi:

1. peran pasif;

2. peran tidak langsung;

3. terinformasi tapi tidak secara aktif memainkan peran; dan

4. peran aktif.

Adapun dari aspek kesempatan dalam partisipasi antara lain dapat dilihat melalui:

1. akses masyarakat untuk ikut serta dalam rapatrapat warga;

2. bagaimana warga menyuarakan aspirasinya melalui wakil-wakilnya; dan

3. adakah peluang masyarakat menyampaikan keluhan atau keberatannya.

Sementara itu, pada dimensi yang lebih luas dari partisipasi, Beckett \& King (2002) mengukur cara warga berpartisipasi antara lain melalui:

1. Kebiasaan rapat-rapat umum dan rapat khusus menyangkut isu-isu tertentu;

2. Visi komunitas atau kelompok-kelompok kepentingan (kelompok ulama, perempuan, petani, pedagang dan sejenisnya).

Model aplikatif penganggaran partisipatif seperti yang berhasil diterapkan di Porto Alegree Brazil membutuhkan prasyarat kualitas partisipasi masyarakat setidaknya pada level citizen power, meminjam istilah yang digunakan Arnstein dalam teori tangga partisipasinya. Dalam kerangka pikir seperti itulah penelitian ini dilakukan.

\section{METODOLOGI PENELITIAN}

\section{Lokus dan Waktu Penelitian}

Penelitian dilakukan di Desa Sasakpanjang Kecamatan Tajurhalang Kabupaten Bogor Provinsi Jawa Barat. Lokus ini dipilih dengan beberapa pertimbangan antara lain;

a. Dana desa untuk Kabupaten Bogor pada tahun 2015 relatif besar yakni Rp130,2 miliar. Adapun alokasi bagi Desa Sasakpanjang pada APBDes 2015 adalah sebesar Rp. 2.050.674.708, jauh di atas rata-rata nasional yang pada tahun 2016 baru mencapai Rp. 1.000.000.000. Pengelolaan APBDes yang sedemikian besar tanpa melibatkan masyarakat akan sulit untuk mencptakan kualitas perencanaan dan pelaksanaan anggaran yang lebih baik.

b. Berdasarkan observasi awal, terdapat indikasi bahwa kedaulatan warga desa kerap masih terpusat di tangan elit desa, hal itupun terjadi di Desa Sasakpanjang. Indikasinya adalah masih belum terselenggaranya musdes sebagai forum tertinggi yang mencerminkan pelaksanaan kedaulatan masyarakat. c. Berdasarkan pengamatan awal lembaga BPD belum mampu melaksanakan tugas pokok dan fungsinya, yaitu menggali, menampung dan menyalurkan aspirasi masyarakat dengan baik.

d. Minimnya informasi tentang program/kegiatan apa yang sedang dan akan dilaksanakan, berapa nilainya dan manfaatnya apa bagi masyarakat dari pelaksanaan program tersebut sering tidak banyak diketahui oleh masyarakat Desa Sasakpanjang.

e. Sebagai daerah penyangga Ibukota, tetapi sebagian besar wilayahnya masih berstatus rural atau desa, tentunya memiliki kekhasan tersendiri dibandingkan dengan daerah-daerah lain yang jauh dari ibukota negara.

\section{Pendekatan Penelitian}

Penelitian ini bersifat kualitatif deskriptif. Metode penelitian kualitatif deskriptif dapat menggambarkan bagaimana partisipasi masyarakat dalam proses perencanaan pembangunan desa yang dijabarkan ke dalam program-program yang tertuang pada APBDes. Pendekatan kualitatif dipandang lebih sesuai digunakan karena melalui penelitian kualitatif dapat menggali informasi dan data secara lebih mendalam, mengingat partisipasi warga dalam perencanaan APBDes merupakan aktivitas yang cukup kompleks.

Dengan pendekatan ini seluk beluk partisipasi masyarakat dalam perumusan APBDes, Desa Sasakpanjang Kabupaten Bogor dapat dipahami secara lebih mendalam. Selain itu pola hubungan antara warga dengan pemerintah desa dalam memperbincangkan dan mendiskusikan persoalanpersoalan yang mereka hadapi dapat dideskripsikan dengan lebih detail.

\section{Pemilihan Informan.}

Sumber informasi dan data dalam penelitian kualitatif diperoleh melalui informan, yang dipilih secara purposive. Pada tahap awal sampel sumber data yang dipilih adalah kepala desa, kemudian dikembangkan lebih lanjut kepada pihak-pihak terkait misalnya perangkat desa yang lain, anggota BPD, dan beberapa tokoh masyarakat yang relevan. Perangkat desa yang dipilih untuk diwawancara adalah 2 orang perangkat desa yang terlibat penuh dalam proses perencanaan anggaran yaitu sekretaris desa dan kepala urusan keuangan. Anggota BPD yang diwawancarai adalah Ketua atau Wakil Ketua BPD. Dari unsur tokoh masyarakat yang dijadikan sebagai informan adalah Ketua RW, tokoh masyarakat, serta perwakilan kelompok masyarakat.

Penelitian dilakukan melalui instrumen sederhana berupa pertanyaan terstruktur maupun tidak terstruktur yang dikembangkan berdasarkan indikator-indikator dan operasionalisasi dari teori tangga partisipasi. 


\section{Teknik Pengumpulan Data}

Pengumpulan data dalam penelitian ini dilakukan melalui berbagai cara, misalnya dengan pengamatan berperan serta, pengamatan dan pencatatan, wawancara, catatan lapangan, dan penggunaan dokumen.

Pengumpulan data dimulai dengan kajian kepustakaan dan mencari dasar teori yang relevan untuk menyusun pertanyaan sesuai dengan aspekaspek yang ingin digali dan didalami. Untuk melihat kualitas atau level partisipasi masyarakat dalam perencanaan APBDes digunakan teori tangga partisipasi Arnstein. Pertanyaan penelitian dikembangkan dari indikator yang relevan pada tiap-tiap tangga untuk memotret level partisipasi masyarakat Desa Sasakpanjang, yang kemudian dituangkan ke dalam pedoman in-depth interview. Di samping itu, partisipasi masyarakat dalam perencanaan APBDes dibagi ke dalam aspek-aspek meliputi, peran, kesempatan, fungsi lembaga dan cara, seperti sudah diuraikan di bagian sebelumnya. Indikator-indikator inilah yang digunakan untuk melakukan proses kodifikasi.

Berbekal dengan aspek dan indikator yang dikembangkan berdasarkan kajian kepustakaan yang dilengkapi dengan data-data sekunder, misalnya data APBDes, dilakukanlah pengumpulan data primer melalui in-depth interview.

Data diperoleh dengan beberapa cara antara lain:

\section{Wawancara secara mendalam (in-depth interview).}

Wawancara mendalam dilakukan dengan mempergunakan teknik wawancara baik terstruktur maupun tidak terstruktur terhadap sejumlah aktor/informan kunci yang meliputi Kepala Desa, Wakil Ketua BPD, satu orang ketua Dewan Kemakmuran Masjid (DKM), satu orang tokoh pemuda, dan dua orang tokoh perempuan. Selain itu wawancara juga dilakukan terhadap Pendamping Desa dan Kepala Seksi Pemerintahan Kecamatan Tajurhalang. Keseluruhan terdapat delapan aktor kunci yang terkait dengan proses perencanaan anggaran di desa. Pedoman wawancara disusun berdasarkan aspek-aspek dan indikator seperti diuraikan di atas.

Para informan ditemui, diwawancara, serta diajak berdiskusi agar diperoleh informasi dan opini yang tajam dan mendalam. Meskipun wawancara dilakukan secara tidak terstruktur, namun tetap dalam kerangka fokus penelitian sesuai pedoman wawancara. Wawancara ini bersifat "open-ended" atau berujung terbuka, yaitu jawaban tidak terbatas hanya pada satu tanggapan.
Setiap wawancara dengan informan kunci dibuat rekamannya kemudian dibuat transkrip dialog, sehingga bisa menjadi informasi dan data untuk merumuskan suatu kesimpulan, dalam rangka menjawab permasalahan penelitian. Melalui wawancara diperoleh informasi mengenai situasi, penjelasan dan permasalahan yang muncul dalam perencanaan APBDes di Desa Sasakpanjang khususnya terkait dengan partisipasi masyarakat ${ }^{1}$.

\section{Telaah Dokumen}

Telaah dokumen dilakukan dengan cara antara lain mengkaji berbagai literatur maupun dokumen peraturan baik yang diterbitkan oleh pemerintah baik pusat maupun daerah di bidang perencanaan dan penganggaran maupun bidang lain yang terkait dengan tata kelola desa. Telaah dokumen juga dilakukan terhadap dokumen risalah rapat atau berita acara pelaksanaan rapat atau musyawarah guna memperoleh gambaran apakah musyawarah sudah dilaksanakan sesuai ketentuan.

Idealnya dilakukan analisis konsistensi antara dokumen hasil penjaringan aspirasi masyarakat melalui forum Musrenbangdes atau Musdes dengan dokumen APBDes, jika dokumendokumen yang diperlukan tersebut diperoleh. Namun demikian, dalam penelitian ini, telaah dokumen minimal dilakukan terhadap postur APBDes serta perkembangan besaran APBDes yang dikelola Desa Sasakpanjang selama kurun waktu tahun anggaran 2015 sampai dengan 2017.

\section{Analisis dan Uji Keabsahan Data}

Dengan menggunakan metode dan sejumlah teknik pengumpulan data baik melalui studi kepustakaan, telaah dokumen, wawancara dan observasi, maka dapat dideskripsikan proses analisis data penelitian sebagai berikut:

\section{Collecting data mentah.}

Proses ini dilakukan dengan mengkaji dan menganalisis literatur dan dokumen kebijakan tentang perencanaan/penganggaran APBDes. Dari aktivitas pada tahap awal ini diperoleh gambaran mengenai proses bisnis perencanaan dan penganggaran di tingkat desa sampai dengan APBDes disahkan. Berdasarkan proses bisnis sesuai peraturan dan literatur disusun pedoman wawancara untuk melakukan in-depth interview.

\section{Transkrip data.}

Pada tahap ini semua hasil wawancara peneliti dengan para informan, dituangkan dalam bentuk

\footnotetext{
${ }^{1}$ Detail dan kodifikasi hasil in-depth interview dapat diperoleh dengan mengirimkan email korespondensi kepada penulis
} 
tulisan di atas kertas. Transkrip data dilakukan secara apa adanya.

\section{Pembuatan coding.}

Secara umum pembuatan koding didasarkan pada sejumlah kata kunci berdasarkan aspek partisipasi masyarakat yang meliputi: (1) peran masyarakat, pemerintah desa dan BPD, (2) kesempatan yang dimiliki masyarakat, (3) cara masyarakat berpartisipasi, (4) kegiatan menggali, menampung dan menyalurkan aspirasi masyarakat yang dilakukan oleh BPD.

\section{Kategorisasi data.}

Setelah dilakukan coding data berdasarkan kata kunci, maka peneliti merangkumnya menjadi beberapa kategori yang lebih sederhana. Kategori yang dibuat menggambarkan pola relasi antara warga dengan pemerintah desa, warga dengan BPD, dan pemerintah desa dengan BPD.

\section{Penyimpulan sementara.}

Kesimpulan sementara diambil dari data-data yang terkumpul, kemudian dilakukan crosscheck atau triangulasi.

\section{Proses triangulasi atau crosscheck.}

Triangulasi dilakukan atas semua temuan penelitian sementara, dengan cara mengalisis kembali kesimpulan sementara dengan teori yang menjadi acuan penelitian. Di samping itu dilakukan crosscheck antara hasil wawancara informan satu dengan informan lain. Triangulasi dilakukan melalui interview mendalam dengan informan yang dianggap kompeten, dalam hal ini misalnya adalah pendamping desa dan Kepala Seksi Pemerintahan Kecamatan Tajurhalang. Kemudian pada akhir tahap ini dilakukan analisis ulang untuk memastikan bahwa temuan di lapangan telah dapat menjawab permasalahan dari penelitian ini.

\section{Penyimpulan Akhir.}

Dari rangkaian kegiatan di atas peneliti selanjutnya mengkonstruksi kesimpulan akhir.

\section{HASIL PENELITIAN DAN PEMBAHASAN}

\section{Proses Perencanaan dan Penganggaran}

Dalam konteks Administrasi Publik, Sukardi (2009) memberikan perspektif bahwa penganggaran adalah salah satu tahapan yang sangat penting dalam pengelolaan pemerintahan. Penganggaran erat hubungannya dengan perencanaan. Aktivitas penganggaran mustahil tidak diawali dengan perencanaan. Mekanisme perencanaan dan penganggaran di tingkat desa diatur melalui berbagai bentuk regulasi, di antaranya adalah Peraturan Menteri Dalam Negeri. Peraturan tersebut, menegaskan bahwa antara proses perencanaan dan penganggaran merupakan satu kesatuan proses yang berkaitan, di mana
APBDes disusun dengan mengacu pada RKPDes sebagai dokumen perencanaan yang berjangka satu tahun.

Mekanisme perencanaan dan penganggaran yang berbasis partisipasi masyarakat sudah diatur di dalam peraturan menteri terkait. Hal ini secara substansi tidak berbeda jauh dengan model aplikatif dalam penganggaran yang berbasis partisipasi warga yang diperkenalkan oleh Brian Wampler (2000). Namun dalam penerapannya belum sepenuhnya mengakomodasi partisipasi dan aspirasi warga masyarakat.

Walaupun ketentuan yang menjadi pedoman proses perencanaan dan penganggaran pada hakekatnya sama, namun dalam kenyataannya terdapat beberapa versi prosedur perencanaan penganggaran yang dipraktikkan di lapangan (Waskitojati, Handoyo, \& Wuryaningsih, 2016). Secara umum interpretasi atas pengaturan proses perencanaan dan penganggaran dapat dijelaskan pada lampiran 5 .

Proses perencanaan dan penganggaran pada berbagai level pemerintahan, termasuk di level desa, selalu mengandung dua proses yang saling mempengaruhi, yaitu proses politik dan proses teknokratis. APBDes berisi program dan kegiatan yang merefleksikan pilihan-pilihan kebijakan hasil pergumulan politik antar elemen masyarakat di tingkat desa sekaligus hasil pertautan argumen rasional yang diformulasi berdasarkan kaidah teknis administratif yang sudah ditetapkan.

BPD menyelenggarakan musdes dalam rangka penyusunan rencana pembangunan desa, sebagaimana telah diatur dalam Pasal 31 Permendagri Nomor 114 Tahun 2014. Hasil musdes menjadi pedoman bagi pemerintah desa menyusun rancangan dan daftar usulan RKPDes. Hasil dari musyawarah desa ini dituangkan dalam bentuk Peraturan Desa tentang Rencana Kerja Pemerintah Desa.

Dari telaah dokumen yang telah dilakukan, di Desa Sasakpanjang musyawarah diselenggarakan oleh pemerintah desa dan dipimpin oleh Kepala Desa, yang dikenal dengan Musrenbangdes. Produk hukum yang dihasilkan dari musyawarah tersebut berupa Peraturan Kepala Desa.

Menurut keterangan Kepala Desa Sasakpanjang, proses perencanaan anggaran di Desa Sasakpanjang dimulai dari kegiatan Musrenbangdes, sebagaimana dituturkan oleh Kepala Desa dalam in-depth interview, tanggal 26 Januari 2019. Pada kesempatan tersebut Kepala Desa menuturkan, bahwa Musrenbangdes merupakan forum untuk mendiskusikan berbagai aspirasi atau usulan kegiatan dari masyarakat. Usulan yang masuk kemudian dipilah dan direkap di tingkat desa, kemudian dibuat skala prioritas tentang kegiatan mana saja yang bisa didanai dengan APBDes. Adapun kegiatan yang tidak bisa ditampung di APBDes dibawa ke Musrenbang tingkat kecamatan 
untuk diusulkan pendanaannya melalui APBD. Peserta yang hadir di forum musyawarah tersebut adalah perwakilan dari Rukun Tetangga, Rukun Warga, tokoh agama, tokoh masyarakat, anggota BPD, lembaga pemberdayaan masyarakat, PKK, kelompok pengajian, dan kader posyandu. Diharapkan dari perwakilan kelompok masyarakat tersebut, baik yang mewakili unsur kewilayahan (RT/RW) maupun mewakili unsur kepentingan (interest group) seperti tokoh agama, kelompok profesi, pemuda, perempuan membawa aspirasi atau usulan yang merepresentasikan kepentingan masing-masing.

Permendagri Nomor 20 Tahun 2018 mengatur proses dan jadwal penyusunan dokumen perencanaan dan penganggaran desa. Musrenbangdes paling lambat dilaksanakan pada bulan Juni tahun anggaran berjalan. Hasil musyawarah tersebut menjadi pedoman bagi pemerintah desa dalam menyusun rancangan RKPDes, yang nantinya akan menjadi dokumen dasar penyusunan APBDes tahun anggaran berikutnya. Berdasarkan hasil wawancara dengan Tenaga Pendamping Desa dan Kepala Seksi Pemerintahan Kecamatan Tajurhalang diperoleh informasi bahwa musdes diselenggarakan dalam dua tahap. Namun dalam praktiknya penyusunan dokumen tersebut sering kali tidak sesuai dengan jadwal waktu yang sudah ditentukan dalam peraturan. Salah satu sebabnya adalah turunnya pagu anggaran tidak tepat waktu. (Wawancara tanggal 31 Januari 2019).

Sekretaris Desa bertanggung jawab dalam Penyusunan Rancangan Peraturan Desa tentang APBDes untuk disampaikan kepada Kepala Desa, untuk kemudian dibahas dengan BPD dalam forum musdes. Rancangan Perdes tentang APBDes disepakati bersama paling lambat bulan Oktober tahun berjalan. Langkah-langkah yang diambil oleh Pemerintah Desa Sasakpanjang dalam merumuskan kegiatan yang diakomodir di dalam APBDes menurut Kepala Desa diprioritaskan untuk usulan kegiatan yang berasal dari wilayah-wilayah yang belum tersentuh pembangunan, berdasarkan survei atau observasi langsung.

Sedikit sekali data dan informasi menyangkut apa saja kesepakatan musyawarah, prioritasprioritas atau sasaran apa yang akan dicapai dan disepakati kemudian ditetapkan dari Musrenbangdes yang sudah dilaksanakan di Desa Sasakpanjang. Karena keterbatasan dokumen yang tersedia, cukup sulit untuk melakukan analisis konsistensi, antara hasil Musrenbangdes, RKPDes dan APBDes. Akibatnya, sulit untuk membandingkan butir-butir kesepakatan apa saja yang diperoleh dalam Musrenbangdes yang kemudian dituangkan ke dalam RKPDes dan APBDes.

Dengan keterbatasan informasi dan dokumen yang bisa diperoleh, tracking dan mapping hanya dapat dilakukan untuk rencana kegiatan tahun anggaran 2015, masing-masing bidang, seperti tertuang dalam lampiran 6.

Secara umum kegiatan yang sudah direncanakan seperti pada lampiran 6 dituangkan dan dilaksanakan melalui APBDes 2015. Namun demikian ada kegiatan yang semula tidak tercantum dalam rencana ternyata dilaksanakan berdasarkan APBDes Perubahan. Kegiatan yang tidak tercantum dalam rencana kegiatan tetapi dilaksanakan antara lain adalah perbaikan drainase (nilai Rp7.165.000) dan pembangunan sumur resapan (5 kegiatan, total nilai Rp12.500.000).

Pada Bidang Pembinaan Kemasyarakatan terdapat kegiatan pemberian bantuan keuangan yang jumlahnya cukup besar yaitu sebesar Rp162.900.000. Sedangkan pada Bidang Pemberdayaan Masyarakat juga terdapat kegiatan pemberian bantuan keuangan dengan nilai sebesar Rp17.495.000.

Dokumen-dokumen perencanaan jangka menengah, RPJMDes Sasakpanjang, sama sekali tidak bisa diperoleh. Hanya dokumen perencanaan RKPDes tahun 2015 saja yang bisa diperoleh, adapun dokumen perencanaan selain 2015 tidak bisa diperoleh. Untuk dokumen APBDes Sasakpanjang tahun-tahun setelah terbit UU Desa, semuanya tersedia. Oleh karena itu tidak bisa dilakukan telaah konsistensi atas program/kegiatan yang tercantum di dalam APBDes. Apakah program/kegiatan yang tertuang di dalam APBDes konsisten dengan dokumen perencanaan yang sebelumnya sudah dibuat, tidak bisa diketahui dengan pasti.

\section{Dokumen Anggaran Pendapatan dan Belanja Desa}

Berdasarkan telaah dokumen APBDes, sumber pendapatan desa Sasakpanjang terdiri dari pendapatan asli desa, pendapatan transfer dan pendapatan lain-lain. Lampiran 7 menunjukkan pendapatan dana dari Desa Sasakpanjang tahun 2015 sampai dengan 2017. Secara umum tren pendapatan meningkat dari tahun ke tahun, di mana sumber peningkatan pendapatan desa adalah dari dana desa yang meningkat dari waktu ke waktu.

Dari lampiran 7 dapat diketahui bahwa pendapatan asli desa belum bisa diandalkan sebagai sumber penerimaan. Jenis pendapatan asli desa masih variatif dari waktu ke waktu. Selama ini Desa Sasakpanjang belum memiliki peraturan yang melembagakan jenis-jenis pungutan yang diakui sebagai sumber pendapatan asli desa. Hal tersebut sekaligus menunjukkan kecenderungan ketergantungan terhadap pendapatan transfer masih sangat tinggi. Kondisi ini perlu diwaspadai agar tidak berlanjut terus dan menjadi kontradiktif dengan amanat undang-undang desa dalam mewujudkan desa yang mandiri dan sejahtera. 
Lampiran 8 menunjukkan komposisi alokasi belanja Desa Sasakpanjang. Belanja desa terbesar adalah bidang pelaksanaan pembangunan desa, yaitu untuk pembangunan rumah tidak layak huni (RUTILAHU) dan pembangunan infrastruktur desa.

\section{Aspek-aspek Partisipasi Masyarakat dalam Perencanaan Anggaran Pendapatan dan Belanja Desa}

Proses perumusan kebijakan publik dalam masyarakat yang modern, demokratis, dengan kekuasaan tertinggi ada di tangan rakyat, sangat tergantung pada kepedulian masyarakat terhadap urusan-urusan pemerintahan (Mufidayati, 2012). Perencanaan anggaran publik dapat disebut sebagai proses politik, karena di dalamnya ada prosesproses perumusan pilihan kebijakan. Kebijakan mana yang akan diambil merupakan hasil dari berbagai macam kepentingan dari berbagai elemen masyarakat yang terlibat di dalamnya. Dalam konteks desa, partisipasi dari masyarakat merupakan unsur kekuatan yang selama ini semestinya menjadi bentuk realitas dari prinsip "partisipasi" warga yang dapat mempengaruhi keputusan atas pilihan kegiatan mana yang akan ditampung di dalam APBDes.

Bagaimana partisipasi masyarakat Desa Sasakpanjang dalam perencanaan APBDes dapat dijelaskan melalui kerangka berpikir, sebagaimana sudah diuraikan pada bab sebelumnya. Mengikuti kerangka berpikir pada bab sebelumnya partisipasi masyarakat diuraikan ke dalam 4 aspek yaitu:
a. Aspek peran
b. Aspek kesempatan
c. Aspek cara
d. Aspek fungsi lembaga BPD

Dari ke empat aspek tersebut di atas diperoleh hasil sebagai berikut:

\section{a. Aspek peran}

Aspek peran dibagi ke dalam beberapa indikator, yaitu:

Kecukupan informasi yang ditandai dengan adanya informasi mendasar tentang APBDes, yang meliputi program/kegiatan apa saja yang direncanakan dan berapa nilainya. Berdasarkan hasil in-depth interview ternyata masyarakat tidak pernah memperoleh gambaran tentang program atau kegiatan yang akan dilaksanakan di desa. Bahkan masyarakat tidak mengetahui berapa besar APBDes yang dikelola oleh Desa Sasakpanjang. Hal ini sesuai dengan penuturan tokoh masyarakat sekaligus sebagai ketua DKM dan pengurus RW (Wawancara tanggal 19 Januari 2019). Hal tersebut dikuatkan oleh ungkapan yang disampaikan informan kunci lainnya, yaitu Wakil Ketua BPD (Wawancara tanggal 5 Januari 2019).

Indikator lain dalam aspek peran masyarakat adalah seberapa besar respon masyarakat. Jika dilihat dari segi partisipasi masyarakat, hasil wawancara menunjukkan bahwa respon masyarakat cukup baik pada forum RT/RW, karena dapat mendiskusikan berbagai persoalan pada forum tersebut. Namun berdasarkan informasi dari Wakil Ketua BPD dan tokoh pemuda, terdapat kendala terkait ketidakcukupan informasi yang diterima masyarakat.

Dari indikator ada tidaknya keterlibatan masyarakat dalam forum-forum yang membahas tentang perencanaan kegiatan yang akan diusulkan ke dalam APBDes diperoleh gambaran yang cukup baik. Berdasarkan informasi dari tokoh agama/tokoh masyarakat, aspirasi masyarakat disalurkan secara berjenjang melalui forum RT, yang dilanjutkan ke forum RW, dan terakhir disampaikan ke forum musdes.

Namun demikian peran pemerintah desa dalam merespon aspirasi dan inisiatif masyarakat belum dilakukan dengan baik. Hasil wawancara dengan informan kunci dari anggota BPD menunjukkan hal itu. "Aspirasi warga itu secara persis belum terpotret dengan baik. Bagaimana kriteria aspirasi/usulan yang akan diakomodasi juga tidak begitu jelas". (Wawancara tanggal 5 Januari 2019). Pemerintah desa kurang memberi ruang dialog kepada masyarakat. Informasi yang diberikan cenderung bersifat monolog.

\section{b. Aspek Kesempatan}

Salah satu indikator pada aspek kesempatan berpartisipasi adalah keterlibatan masyarakat dalam proses perencanaan. Berdasarkan wawancara diperoleh data bahwa masyarakat dilibatkan dalam proses perencanaan walaupun tidak secara langsung. Partisipasi masyarakat diberikan hanya melalui penyampaian aspirasi secara berjenjang. Namun sejauh mana aspirasi masyarakat akan mempengaruhi kebijakan APBDes tergantung pada pertimbangan Kepala Desa. Masyarakat hanya sebatas mengusulkan kegiatan namun tidak sampai pada perhitungan anggarannya, sehingga tidak memiliki kontrol atas kegiatan yang mereka usulkan. Pengakuan informan kunci dari tokoh muda dan tokoh agama, di bawah ini menunjukkan hal itu:

"Dari aspirasi yang disampaikan, secara umum masyarakat tidak mempunyai kontrol. Apakah usulan yang diajukan diterima atau tidak. Biasanya usulan yang diajukan tidak langsung direspon atau mendapat persetujuan, bahkan baru sekali usulan perbaikan jalan disetujui, itupun tidak sepenuhnya". (Wawancara tanggal 26 Januari 2019).

\section{c. Aspek Cara}

Indikator pada aspek cara ini antara lain adalah adanya forum-forum yang memberikan tempat bagi masyarakat menyampaikan pandangannya terhadap usulan intervensi pemerintah tertentu yang dilakukan secara 
berjenjang mulai dari tingkat RT, RW, dan kemudian ke tingkat desa. Proses mendiskusikan berbagai pilihan kegiatan yang akan diusulkan di tingkat desa dilakukan dalam kelompok-kelompok kecil, misalnya kelompok pengajian atau pertemuanpertemuan warga di level RT yang diselenggarakan secara rutin, mingguan, dua mingguan atau bulanan. Semakin kecil forumnya, semakin sering frekuensi pelaksanaannya.

\section{d. Aspek fungsi lembaga BPD}

Dalam proses perencanaan anggaran partisipatif terdapat dua arah komunikasi, yaitu bottom-up dan top-down, yang melibatkan berbagai pihak antara lain masyarakat, individu tertentu yang menjadi tokoh, lembaga informal maupun formal. Lembaga formal di desa yang seharusnya berperan penting adalah Pemerintah Desa dan BPD. Terkait dengan peran BPD sebagai lembaga formal instrumen demokrasi di tingkat desa, diperoleh gambaran dari Wakil Ketua BPD (Wawancara, tanggal 5 Januari 2019). Berdasarkan hasil wawancara tersebut, BPD kurang dapat menjalankan perannya dengan baik sebagai lembaga penampung dan penyalur aspirasi masyarakat. BPD tidak menjalankan fungsi dalam menampung dan menyalurkan aspirasi masyarakat secara formal melalui struktur organisasi yang ada. Tidak dilakukan dokumentasi tertulis atas aspirasi yang disampaikan masyarakat karena tidak adanya dukungan operasional kesekretariatan dan ketidakjelasan mekanisme penyampaian aspirasi oleh masyarakat.

Bagaimana peran BPD di mata masyarakat terwakili oleh ungkapan yang disampaikan oleh tokoh masyarakat sekaligus ketua DKM dan pengurus RW. Menurutnya, BPD tidak mampu menjadi jembatan komunikasi antara warga masyarakat dengan Pemerintah Desa sebagai pemegang kekuasaan eksekutif. Komunikasi dua arah antara warga dengan Pemerintah Desa diperlukan dalam penyusunan anggaran yang aspiratif karena masyarakat akan merespon secara memadai sesuai dengan informasi yang diperolehnya. Ketiadaan informasi yang relevan dan memadai yang dimiliki oleh masyarakat akan menyebabkan partisipasi masyarakat terhambat (Wawancara tanggal 19 Januari 2019).

\section{Derajat Partisipasi Masyarakat dalam Perencanaan APBDes}

Anggaran Pendapatan dan Belanja Desa yang dikelola oleh Desa Sasakpanjang relatif besar, dan menunjukkan tren yang meningkat dari waktu ke waktu. APBDes yang besar berpotensi untuk mendorong tercapainya kemandirian dan kesejahteraan masyarakat desa setempat. Kunci dari tercapainya kemandirian dan kesejahteraan masyarakat desa setempat adalah pada bagaimana program-program dan kegiatan yang ditampung di dalam APBDes mampu mengakomodasi semaksimal mungkin aspirasi dan kebutuhan riil yang ada di masyarakat. Penyusunan APBDes tidak sekadar proses administratif yang hanya dimonopoli oleh pemerintah desa, tetapi juga harus dipandang sebagai proses politik di tingkat desa. Sebagai sebuah proses politik, lahirnya suatu kebijakan mestinya melalui dialog interaktif yang melibatkan berbagai kalangan di desa, sehingga APBDes sebagai refleksi dari kebijakan tersebut, mampu menampung sebesar-besarnya aspirasi masyarakat (Mariana, 2015).

Partisipasi masyarakat dalam perencanaan APBDes dapat dikategorikan ke dalam empat aspek meliputi peran, kesempatan, cara dan fungsi lembaga BPD, seperti sudah diuraikan pada bagian sebelumnya. Secara umum masyarakat sudah ikut berperan dan memiliki kesempatan berpartisipasi dalam perencanaan. Masyarakat juga sudah memiliki cara menyalurkan aspirasinya. Namun demikian masyarakat belum memiliki kontrol yang cukup dalam mempengaruhi kebijakan yang tercermin di dalam APBDes. Informasi mendasar tentang APBDes tidak tersampaikan ke warga masyarakat. Pemerintah Desa terkesan berjalan sendiri dalam perumusan program/kegiatan yang ditampung di dalam APBDes. Hal ini terjadi karena tugas fungsi BPD belum dilaksanakan dengan baik.

Komunikasi dua arah antara warga masyarakat dengan pemerintah desa sebagai penentu kebijakan sering kali hanya terjadi di tingkat elit para pengambil keputusan. Kelompok-kelompok masyarakat lain yang nantinya akan terdampak kebijakan tersebut, sering tidak dilibatkan. Begitupun yang terjadi di Desa Sasakpanjang dalam proses formulasi kebijakan APBDesnya. Kesan dominasi elit ini begitu kuat di Desa Sasakpanjang, seperti diungkapkan oleh Wakil Ketua BPD, bahwa masyarakat di wilayah desa Sasakpanjang sudah berpartisipasi dengan antusias, namun tidak terjadi proses dialog dalam penyusunan kebijakan. BPD sebagai lembaga yang merepresentasikan warga tidak diajak dalam penentuan anggaran. Kesan dominasi elit (Kepala Desa) begitu kuat (Wawancara tanggal 5 Januari 2015).

Dalam masyarakat yang modern, demokratis, dan terbuka mestinya terjadi keseimbangan antara proses bottom-up (aspirasi yang munculnya dari masyarakat) dan top-down (informasi atau arahan dari pemerintah desa), sehingga menghasilkan kebijakan APBDes yang aspiratif. Proses penganggaran merupakan kombinasi antara aktivitas politis versus proses teknokratis. Proses teknokratis menyangkut perumusan asumsi-asumsi dan proyeksi yang terukur. Proses teknokratis dilakukan oleh aparat desa, dalam bentuk bagaimana menyusun target-target pendapatan, kapasitas pendanaan dan merumuskan kinerja anggaran (outcome) yang obyektif dan terukur. Undang-Undang Nomor 6 tahun 2014 tentang Desa telah didesain sedemikian rupa sehingga dialog 
yang mengakomodasi proses politis dan teknokratis ini dapat terlaksana melalui institusi Badan Permusyawaratan Desa (BPD). Namun, dalam kontek Desa Sasakpanjang, BPD belum bisa menjalankan peran sesuai tugas pokok dan fungsinya dengan baik. Ungkapan tokoh masyarakat berikut ini menunjukkan hal tersebut:

"Mengenai peran BPD selama ini dilingkungan boleh dikata tidak ada peran sama sekali, baik untuk menjembatani aspirasi dari bawah maupun penyampaian informasi, atau program-program dari atas". (Wawancara tanggal 19 Januari 2019)

Fungsi BPD menurut Peraturan Menteri Dalam Negeri Nomor 110 Tahun 2016 tentang Badan Permusyawaratan Desa, antara lain adalah menampung dan menyalurkan aspirasi masyarakat Desa. Berdasarkan regulasi tersebut BPD memiliki kewenangan untuk memecahkan kebuntuan komunikasi antar elemen di desa, melalui proses penggalian dan pengelolaan aspirasi masyarakat.

Banyak tugas BPD Sasakpanjang yang belum dapat dilaksanakan secara maksimal, seperti diungkapkan oleh Wakil Ketua BPD Sasakpanjang, sebagai berikut:

"Rapat intern BPD untuk memberikan pandangan tentang suatu hal tertentu kepada Kepala Desa/Pemerintah Desa secara resmi gak pernah ada. Yang ada adalah ngobrol informal dengan beberapa unsur pimpinan BPD, sambil ngasih honor, jadi tidak ada agenda resmi, inilah salah satu kelemahan BPD. Makanya saya sering bingung, informasi apa yang harus saya sampaikan kepada masyarakat RW yang saya wakili. Jadi BPD ini sebagai lembaga formal yang menyuarakan aspirasi masyarakat tumpul". (Wawancara tanggal 5 Januari 2019)

Bagaimana BPD menggali, menampung, mengelola dan menyalurkan aspirasi masyarakat sebenarnya telah diatur oleh Pemerintah, namun dalam praktiknya di Desa Sasakpanjang, hal tersebut belum terselenggara sesuai ketentuan (Wakil Ketua BPD, wawancara tanggal 5 Januari 2019).

Sesuai regulasi, BPD berwenang untuk mengadakan forum-forum musyawarah masyarakat. Melalui forum-forum tersebut, masyarakat dapat diedukasi untuk menyampaikan aspirasinya secara argumentatif. Melalui forum musyawarah tersebut, masyarakat dapat saling bertukar ide dan gagasan. Namun sayangnya hal tersebut belum bisa dilakukan oleh masyarakat Desa Sasakpanjang.

Dialog antar pihak yang memiliki latar kepentingan yang berbeda di masyarakat Sasakpanjang belum terlihat nyata dalam mempengaruhi hasil kesepakatan yang akan menentukan isi dari kebijakan APBDes. Derajat partisipasi masyarakat di Desa Sasakpanjang masih dalam kategori yang lemah. Model demokrasi deliberatif yang mampu meminimalkan potensi distorsi pada formulasi kebijakan belum terlihat dalam penyelenggaraan otonomi desa di Sasakpanjang. Hubungan suprastruktur desa dengan warganya masih cenderung monolog, walaupun sebenarnya keran demokrasi sudah terbuka lebar.

Jika dilihat menggunakan tangga partisipasi Arnstein, hubungan kemitraan antara masyarakat desa dengan pemerintah desa belum terjalin dengan baik. Dialog kosntruktif argumentatif yang relatif setara antara warga dengan kepala desa sebagai pemegang kekuasaan tertinggi pengelolaan keuangan desa belum terjadi. Kemitraan antara pemerintah desa dengan warganya untuk membicarakan perencanaan dan pengembangan keputusan kolektif yang diakomodir di dalam APBDes melalui fasilitasi BPD belum berjalan semestinya.

Partisipasi masyarakat Desa Sasakpanjang dalam perumusan APBDes, jika dianalisis menggunakan tangga partisipasi Arnstein berada pada derajat peredaman. Aspirasi masyarakat sudah mulai mempengaruhi kebijakan pemerintah desa, walaupun masih bersifat lip service. Kebijakan APBDes yang dibuat oleh pemerintah Desa Sasakpanjang belum didasarkan pada hasil kesepakatan dari pertukaran argumentasi dalam posisi yang setara masing-masing stakeholder di desa. Walaupun di tengah-tengah warga terdapat banyak kelompok-kelompok semacam jemaah pengajian, forum RT/RW dan sejenisnya yang sering dijadikan sebagai forum mendiskusikan persoalan dan kebutuhan riil yang mereka ingin pecahkan. Namun masyarakat belum mampu mendorong kepentingannya agar diakomodasi oleh pemerintah desa. Lembaga formal permusyawaratan masyarakat (BPD) sudah terbentuk, namun belum bisa secara efektif mengelola aspirasi masyarakat. Peran BPD tidak signifikan dalam pengambilan keputusan terkait APBDes, dan sering kali hanya menjadi alat stempel pemerintah desa saja.

Public hearing melalui forum musdes maupun musrenbangdes telah dilakukan, namun sayangnya masyarakat tidak diberikan kesempatan untuk mencurahkan aspirasi dan gagasannya. Aspirasi yang berkembang di masyarakat belum diperhatikan dan dipertimbangkan dalam kebijakan yang akan dibuat, melainkan hanya ditampung namun tidak ada jaminan bahwa usulan tersebut akan diakomodir di dalam APBDes. Ungkapan Tenaga Pendamping Desa menunjukkan hal itu:

"Pandangan ada mungkin pak cuma gak terlalu ... udah selesai ...Karena pertanyaan kan mungkin hanya ya nanya-nanya katakanlah tidak sampai ada semacam mempersoalkan gak misalnya, oh usulan saya kok engga, kan di forum itu mungkin 
belum diputuskan, baru istilahnya menampung". (Wawancara tanggal 31 Januari 2019)

Pemerintah desa menggunakan forum musdes dan musrenbangdes untuk sekadar menciptakan kesan bahwa masyarakat telah turut berpartisipasi, dan sekadar memenuhi prosedur formal yang ditentukan oleh pemerintahan di atasnya.

Berdasarkan analisis yang dilakukan pada partisipasi masyarakat desa Sasakpanjang dalam perencanaan APBDes menggunakan tipologi Arnstein, derajat partisipasi berada pada level peredaman dalam degree tokenism. Ringkasan hasil penelitian menggunakan tangga partisipasi Arnstein disajikan di lampiran 9.

\section{Faktor Penghambat dan Pendukung Partisipasi Masyarakat Desa Sasakpanjang dalam Perencanaan APBDes}

Inti perlunya partisipasi masyarakat dalam perencanaan APBDes adalah untuk memastikan bahwa kebijakan yang dibuat pemerintah desa mengakomodasi kebutuhan yang mampu menyelesaikan persoalan riil masyarakat. Semakin tinggi kualitas partisipasi semakin mampu memberi warna pada kebijakan yang diputuskan. Indikator dari tingginya kualitas partisipasi masyarakat dapat diukur menggunakan tangga partisipasi Arnstein. Makin tinggi letak tangga partisipasi, makin berkualitas level partisipasi masyarakat. Pokok masalahnya adalah, bagaimana masyarakat benarbenar mampu menyalurkan aspirasinya? Sebelum menjawab pertanyaan ini tentunya perlu diketahui siapa saja aktor-aktor kunci dalam proses penjaringan aspirasi masyarakat. Aktor-aktor kunci dalam penjaringan aspirasi masyarakat antara lain adalah sebagai berikut:

1. BPD yang melaksanakan fungsi legislatif di tingkat desa sebagai pemegang kewenangan utama dalam pengelolaan aspirasi masyarakat, serta menyelenggarakan musyawarah desa;

2. Perangkat pemerintah desa, yang menjalankan fungsi eksekutif/pengambil keputusan;

3. Pemimpin informal masyarakat, seperti tokohtokoh agama, tokoh masyarakat yang tergabung dalam Lembaga Swadaya Masyarakat (LSM), kelompok tani/pedagang/profesi lainnya, kelompok perempuan/pemuda, dan lain-lain; dan

4. Tenaga pendamping desa yang memberikan advokasi dan pemberdayaan kepada pemerintah desa atau masyarakat.

Para pihak di atas adalah subjek dari proses diskusi publik dalam mengagregasi aspirasi masyarakat. Kondisi yang terkait dengan subjeksubjek tersebut menjadi faktor yang bisa mendukung atau menghambat partisipasi masyarakat.
BPD selaku pemegang kewenangan legislatif di Desa Sasakpanjang belum bisa memainkan perannya dengan baik karena beberapa hal. Wakil Ketua BPD Sasakpanjang mengungkapkan hal tersebut:

"Mereka itu butuh intelektual. Anggota BPD itu butuh wawasan banyak ....".

“... Sekretariat BPD ada di desa, tapi tidak ada staf sekretariat yang menangani ...".

“... Nah ini ada yang intelektual, tetapi ada kendala waktu jadi jarang hadir di rapat. Gitu loh, boroboro nyumbang saran ...". (Wawancara tanggal 5 Juli 2019)

Ungkapan di atas menyiratkan bahwa faktor yang menjadi penghambat bagi munculnya partisipasi masyarakat, yang terkait dengan institusi BPD antara lain adalah:

1. Kapasitas dan kompetensi anggota BPD. Kompetensi dalam hal ini menyangkut baik hard competency maupun soft competency. Hard competency antara lain menyangkut pengetahuan terkait regulasi di bidang tata kelola sumber daya keuangan desa dan kompetensi dalam melakukan need assessment masyarakat pada tingkat akar rumput (grass root). Sedangkan aspek soft competency mencakup dan tidak terbatas pada kemampuan mendengarkan dan melayani, mengkategorikan setiap argumen atau pendapat yang muncul agar pembicaraan menjadi konstruktif.

2. Dukungan operasional kesekretariatan yang belum memadai, sehingga masyarakat kesulitan untuk menyampaikan aspirasi.

3. Kendala waktu yang dimiliki masing-masing anggota, sehingga menyulitkan dalam mengagendakan pertemuan-pertemuan dengan warga yang terjadwal secara konsisten.

Perangkat pemerintah desa, yang menjalankan fungsi eksekutif/pengambil keputusan, berperan sebagai fasilitator dan mendorong diskusi-diskusi tematis berdasarkan kebutuhan yang dirasakan oleh warga. Namun peran ini masih sulit dilaksanakan, karena beberapa sebab, salah satunya, menurut Wakil Ketua BPD, adalah keterbatasan kapasitas sumber daya manusia perangkat Desa. Hal ini disebabkan karena adanya patronase politik misal karena menjadi tim sukses sewaktu pilkades, dan faktor kekerabatan, yang kesemuanya itu mengesampingkan faktor kompetensi dan keterampilan teknis (Wawancara tanggal 5 Januari 2019).

Hal lain yang menyebabkan terhambatnya partisipasi warga masyarakat yang terkait pada unsur pemerintah desa adalah, kurang berperannya Sekretaris Desa, Sebagaimana diungkapkan oleh Kepala Desa Sasakpanjang (Wawancara tanggal 26 Januari 2019). 
Sesuai ketentuan Sekeretaris Desa menyusun Rancangan Peraturan Desa tentang APBDes berdasarkan RKPDes untuk disampaikan kepada Kepala Desa. Rancangan Peraturan Desa tentang APBDes dibahas dan disepakati bersama BPD melalui musyawarah desa. Dengan demikian, Sekretaris Desa memiliki peran penting dalam perencanaan APBDes, namun peran tersebut tidak dijalankan sesuai peraturan sebagaimana tergambar dari ungkapan Kepala Desa di atas.

Dari berbagai argumen di atas dapat ditarik konklusi bahwa yang menghambat partisipasi masyarakat yang berkaitan dengan Kepala Desa maupun perangkatnya adalah:

1. Kepala Desa belum mempunyai komitmen untuk menghilangkan jaringan patronase politik yang berpengaruh terhadap rekrutmen SDM pemerintah desa. Hal ini berakibat pada standar kualitas SDM perangkat desa belum memadai.

2. Kesediaan pemerintah desa untuk mendelegasikan kekuasaannya kepada warga atau institusi lainnya di desa. Hal ini bisa dilakukan dalam bentuk, memberikan kelonggaran kepada warga untuk dapat merencanakan dan mengelola program/kegiatan sesuai kapasitas sumber daya keuangan desa.

3. Ketiadaan leadership pada pemerintah desa yang berakibat pada ketiadaan strategic vision, yang bisa menggugah timbulnya pertukaran gagasan ditengah-tengah masyarakat.

Hal terkait lain yang menghambat partisipasi masyarakat adalah adanya trade-off antara ketersediaan anggaran dengan banyaknya kebutuhan riil masyarakat yang harus diselesaikan. Seperti diungkapkan oleh Kepala Desa bahwa ada kendala keterbatasan anggaran jika dibandingkan dengan banyaknya kebutuhan riil masyarakat yang harus dipecahkan. Konsekuensi logis dari hal ini adalah, mengharuskan pemerintah desa membuat skala prioritas. Ada usulan kegiatan yang didahulukan, ada yang mendapat giliran belakangan. Bagi sebagian masyarakat yang tidak tertampung aspirasinya, dapat menimbulkan apatisme, apa lagi jika tidak ada kepastian kapan aspirasi suatu kelompok masyarakat akan diakomodasi di dalam APBDes (Wawancara tanggal 26 Januari 2019).

Makna substantif dari partisipasi masyarakat dalam pembuatan kebijakan APBDes pada prinsipnya adalah tidak adanya pihak yang mendominasi substansi kebijakan yang diakomodasi di dalam APBDes. APBDes sebagai cerminan dari kebijakan publik di tingkat desa, hakekatnya merupakan suatu bentuk konsensus di antara elemen-elemen masyarakat desa. Proses pembuatan konsensus ini bisa dilakukan melalui forum-forum curah gagasan, bisa forum informal semacam jemaah pengajian mingguan, forum pertemuan warga di tingkat RT atau RW, dan forum formal semacam Musyawarah Desa. Forum-forum tersebut dijadikan sebagai ajang pertukaran gagasan. Dominasi substansi kebijakan oleh pihakpihak tertentu bisa dihindari jika ada kesetaraan dari para pihak yang terlibat dalam forum musyawarah. Keterlibatan masyarakat Desa Sasakpanjang dalam mengelola persoalan kolektif mereka diungkapkan oleh tokoh muda Sasakpanjang sebagai berikut:

1. Kepedulian masyarakat Desa Sasakpanjang dengan persoalan kolektif masih rendah, walaupun kegotongroyongannya masih tinggi.

2. Menghindari perbedaan pandangan (termasuk menyampaikan kritik kepada pihak lain) demi menjaga keharmonisan hubungan dengan sekitarnya.

3. Kepeloporan dan ketokohan masih kurang. (dirangkum dari hasi wawancara tanggal 26 Januari 2019)

Faktor-faktor di atas menjadi penghambat masyarakat dalam berpartisipasi mendialogkan dan mencari jalan keluar bagi penyelesaian masalahmasalah riil yang mereka butuhkan. Masyarakat cenderung enggan untuk berbeda pandangan secara terbuka dengan pemerintah desa atau pihakpihak yang memiliki otoritas dalam mengambil kebijakan. Hal itu disebabkan karena pihak-pihak yang terlibat dalam dialog atau perdebatan ini adalah kerabat mereka sendiri. Kehidupan masyarakat di pedesaan Sasakpanjang masih kental nuansa komunal dan paternalnya. Masyarakat Desa Sasakpanjang sebenarnya membutuhkan pendampingan dalam peningkatan keterampilan dalam mengemas narasi dan menyampaikan argumentasi agar gagasan-gagasan mereka bisa ditangkap dengan baik oleh pihak-pihak lain terutama pada forum-forum diskusi formal.

Dalam upaya mendorong masyarakat mampu secara mandiri melakukan pembaharuan dan pembangunan desanya secara mandiri, diperlukan proses fasilitasi oleh pendamping desa. Tugas pendamping desa menurut ketentuan adalah, mengembangkan kapasitas, dan melakukan pendampingan kepada para kader penggerak pembangunan desa. Namun praktik pendampingan yang terjadi di Desa Sasakpanjang berdasarkan pernyataan pendamping desa dan Kepala Seksi Pemerintahan Kecamatan Tajurhalang adalah sebagai berikut:

“... desa itu kita tuh mendorong pake form pengusulan, di bawa ke RT RT ... Nah setelah proses itu dilalui maka kemudian di desa itu musrenbangdes. Mana yang jadi ... secara teori kan kita harus mikir dulu... baru diajukan ke RT.

.... kita potong kompas nggak ada, khusus tuh langsung ke RT RT usulan itu. Memang form itu sudah dikasih ke RT, lewat RT lewat RW tapi sebelumnya dikumpulin, kumpulin terkait kalau ada agenda perencanaan kegiatan, pembangunan 
tahun 2020 misalnya. Biasanya kita bulan juni kita tuh ... RT RW itu untuk melakukan ... ke bawah dengan partisipasi ... diserahkan di tingkat bawah. Dokumen-dokumen ini memang kita juga harus diakui bahwa 1 , fungsinya kenapa... pendamping ini lemahnya SDM di salah satunya ... ada yang namanya pendamping profesional itu sebutannya ... pendamping desa...

Yah kita karena tadi kan prosesnya tuh di lingkungan. Nah maka kemudian kita dorongnya sebenarnya ada pertemuan kader kita dorong...". (Wawancara tanggal 31 Januari 2019)

Jika dicermati secara mendalam, pernyataan di atas menggambarkan pendampingan yang bersifat administratif, dibandingkan membangkitkan kesadaran politik warga desa melalui kader-kader pembangunan desa.

Hal yang mendesak untuk dikembangkan pada masyarakat desa Sasakpanjang, melalui lembagalembaga formal desa adalah kapasitas teknokratis yang meliputi perencanaan, penganggaran, keuangan, dan keterampilan teknis lainnya yang dapat meningkatkan partisipasi masyarakat desa. Namun yang terjadi di desa Sasakpanjang, pendamping desa sulit membedakan antara tugas pengawalan dana desa dengan tugas pendampingan yang lebih bertujuan pada pemberdayaan masyarakat desa.

Jika hal-hal yang menghambat partisipasi masyarakat tersebut dapat teratasi maka derajat partisipasi masyarakat Desa Sasakpanjang akan meningkat. Peningkatan derajat partisipasi dari level semu ke level yang lebih nyata, maka model participatory budgeting ala Wampler tidak mustahil berhasil diimplementasikan. Faktor pendukung bagi suksesnya implementasi model aplikatif penganggaran berbasis masyarakat di Desa Sasakpanjang sudah dan masih dimiliki, antara lain: 1. Sistem organisasi sosial, semacam jemaah pengajian, kelompok tani dan lembaga kemasyarakatan yang lain sudah terbentuk secara alami. Pertemuan-pertemuan rutin di antara anggota kelompok sering dilakukan

2. Aturan main yang ada dengan terbitnya UndangUndang Nomor 6 Tahun 2014 tentang Desa sudah memberi peluang yang lebar untuk tumbuhnya partisipasi masyarakat dalam merumuskan kebijakan.

3. Semangat kegotongroyongan masih cukup tinggi di tengah masyarakat Sasakpanjang, karena corak lingkungan pedesaan yang guyub masih terpelihara.

\section{KESIMPULAN}

Temuan penting penelitian ini adalah bahwa partisipasi masyarakat Desa Sasakpanjang berada pada level peredaman dalam degree of tokenism.
Masyarakat memiliki kesempatan berpartisipasi dan cara menyalurkan aspirasi, namun belum berpengaruh terhadap pengambilan keputusan di desa, sifatnya masih semu.

Terdapat beberapa hal yang menjadi penghambat partisipasi masyarakat antara lain, yaitu :

- Anggota BPD tidak memahami tugas dan fungsinya. Kompetensi administrasi bidang perencanaan dan penganggaran dinilai masih rendah, adapun tugas memandu dan menggalang partisipasi masyarakat terabaikan.

- $\quad$ Leadership dan ketokohan baik di lembaga formal desa (BPD dan pemerintah desa), lembaga kemasyarakatan dan tokoh informal masih rendah. Kemampuan mendengarkan dan melayani, mengkategorikan setiap argumen atau pendapat yang muncul, mengartikulasikan gagasan dan ide, dan membangun pembicaraan atau curah pendapat menjadi konstruktif masih perlu ditingkatkan.

- Pola kehidupan komunal masyarakat dan budaya "ewuh pekewuh" menghambat tumbuhnya pertukaran gagasan-gagasan yang konstruktif. Perbedaan pendapat cenderung dihindari demi menjaga keharmonisan hubungan dengan sekitarnya.

Penelitian ini memiliki keterbatasan, karena hanya dilakukan di satu desa tertentu. Temuan yang dihasilkan dari penelitian ini tentunya belum menggambarkan situasi dan masalah pada ribuan desa yang lain, sehingga tidak bisa dilakukan generalisasi. Keterbatasan lain, penelitian ini baru sebatas menggambarkan partisipasi masyarakat pada tahap perencanaan/penganggaran. Untuk melihat tata kelola keuangan desa pada dimensi yang lebih luas dan lebih lengkap disarankan untuk dilakukan penelitian partisipasi masyarakat pada tahap-tahap yang lain, misal pelaksanaan dan pengawasan anggaran, serta melibatkan sampel desa yang lebih banyak.

\section{REFERENSI}

Arnstein, S. R. (1969). A Ladder of Citizen Participation, Journal of The American Institute of Planners, 35 (4), 216-224.

Artha, A. (2018). Partisipasi Masyarakat Dalam Pelaksanaan Program Dana Desa, Tesis tidak dipublikasikan, UGM Yogyakarta.

Beckett, J., \& King, C. S. (2002). The challenge to improve citizen participation in public budgeting: A discussion. Journal of Public Budgeting, Accounting \& Financial Management. 14(3), 463-485. 
Creighton, J. L. (2005). The Public Participation Handbook Making Better Decicion Through Citizen Involvement, Jossey Bass A Wiley Imprint, San Fransisco.

Gaventa, J. \& Valderrama, C. (1999). Participation, Citizenship and Local Governance, Background note prepared for workshop on 'Strengthening participation in local governance Institute of Development Studies'. https://www.uv.es/ fernandm/Gaventa,\%20 Valderrama.pdf di download tanggal 18 Juni 2019 jam 0.55 WIB.

Hadi, A. P. (2009). Konsep Pemberdayaan, Partisipasi Dan Kelembagaan Dalam Pembangunan, Yayasan. Agribisnis/Pusat Pengembangan Masyarakat Agrikarya (PPMA), Jakarta.

Irawan, N. (2017). Tata Kelola Pemerintahan Desa Era UU Desa, Yayasan Pustaka Obor Indonesia, Jakarta.

Isnadi. (2007). Proses Perencanaan Partisipatif Dalam Pembangunan Daerah Kabupaten Kebumen. Tesis: Pascasarjana Universitas Brawijaya Malang

Mardiyanta, A. (2013). State of the art: Konsep partisipasi dalam ilmu administrasi publik State of the art: Participation concept in public administration. Masyarakat, Kebudayaan Dan Politik, 26, 227-242.

Mariana, D. (2015). Partisipasi Masyarakat dalam Proses Kebijakan, Jurnal Ilmu Pemerintahan, ISSN 2442-5958 Vol.1 No.2.

Mufidayati, K. (2012). Implementasi Kebijakan Manajemen Berbasis Sekolah (MBS) pada SekolahDasar Negeri dan Sekolah Menengah Pertama Negeri Rintisan Sekolah Bertaraf Internasional (RSBI) di DKI Jakarta, Desertasi tidak dipublikasikan, Universitas Indonesia.

Nugroho Y. (2019, Januari 16). UU Desa Penting untuk Kedaulatan Desa. Kompas. H.4.

Orosz, J. F. (2002). Views From The Field: Creating A Place For Authentic Citizen Participation In Budgeting, Journal of Public Budgeting, Accounting \& Financial Management, 14(3), 423-444.

Raharjo, P. (2017). Musyawarah Rencana Pembangunan Desa Sebagai Arena Pertautan Teknokrasi Dan Partisipasi Masyarakat Desa (Studi Kasus Desa Panggungharjo Sewon Bantul), Tesis tidak dipublikasikan UGM Yogyakarta.

Sijabat \& Cahyono. (2016). Studi Pengelolaan APBDes Pasca Undang-Undang Desa (Kasus Desa Sukadiri Kecamatan Sukadiri Kabupaten Tangerang Provinsi Banten dan Desa Sasak Panjang Kecamatan Tajur Halang Kabupaten Bogor Provinsi Jawa Barat), Laporan Kajian Akademis tidak diterbitkan, Pusdiklat Anggaran dan Perbendaharaan, Bogor.

Sopanah, A. (2012). Ceremonial budgeting: public participation in development planning at an
Indonesian local government authority. Journal of Applied Management Accounting Research, 10(2), 73.

Sukardi, A. (2009). Participatori Governance dalam Pengelolaan Keuangan Daerah, LaksBang PRESSindo, Yogyakarta.

Sumpeno, W. (2013). Perencanaan Desa Terpadu, Penerbit Read, Banda Aceh.

Wampler, B. (2000). A Guide to Participatory Budgeting, The International Budget Object, Washington, D.C.

Waskitojati, D., Handoyo, S., Wuryaningsih, C. D., Prasetyo, H. D., \& Luwihono, S. (2016). Policy Note: Model Proses Penganggaran Pembangunan Desa Secara Partisipatif. Jawa Tengah: Lembaga Percik Salatiga. 


\section{ILUSTRASI GAMBAR}

Lampiran 1. Kontinum bergerak ke kanan menunjukkan makin besar tingkat keterlibatan masyarakat.

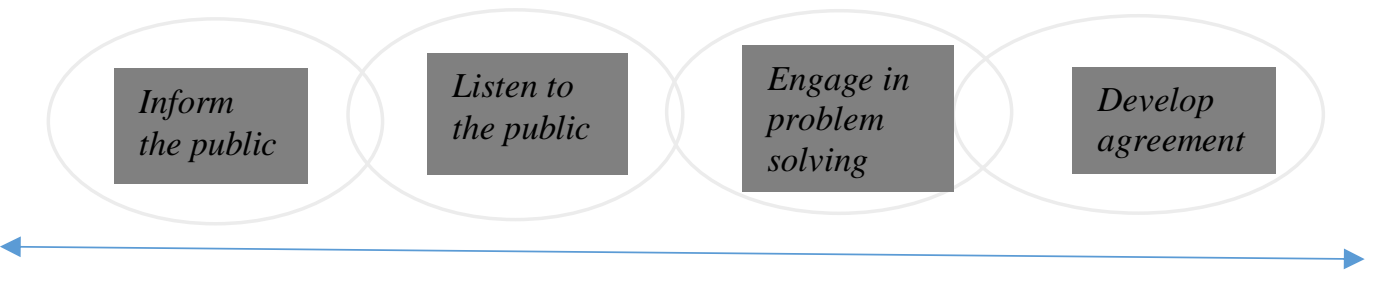

\section{Lampiran 2. Siklus Tahunan Anggaran Berbasis Partisipasi Warga}

Participants

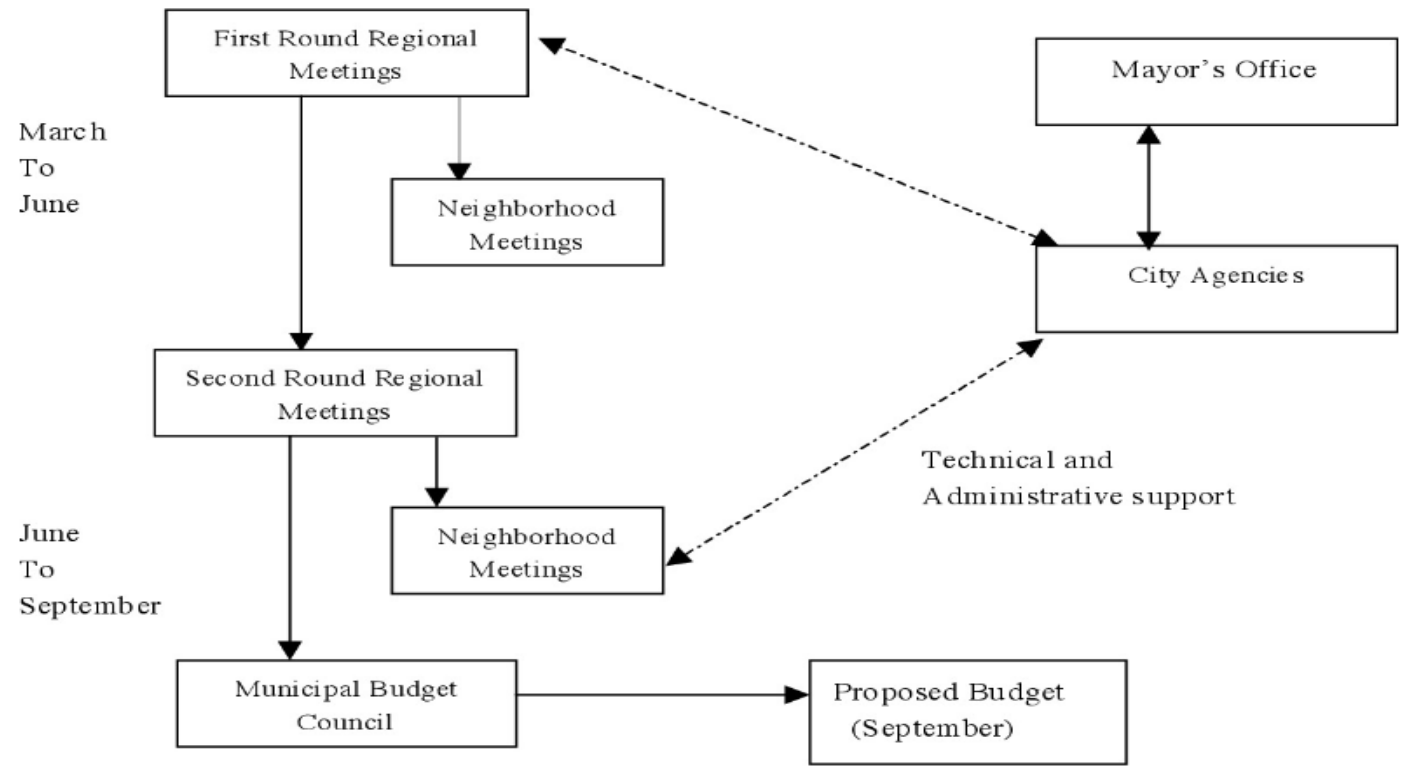

Sumber: A Guide to Participatory Budgeting (Wampler, 2000)

Lampiran 3. Alur Partisipasi Masyarakat dalam Perencanaan APBDes

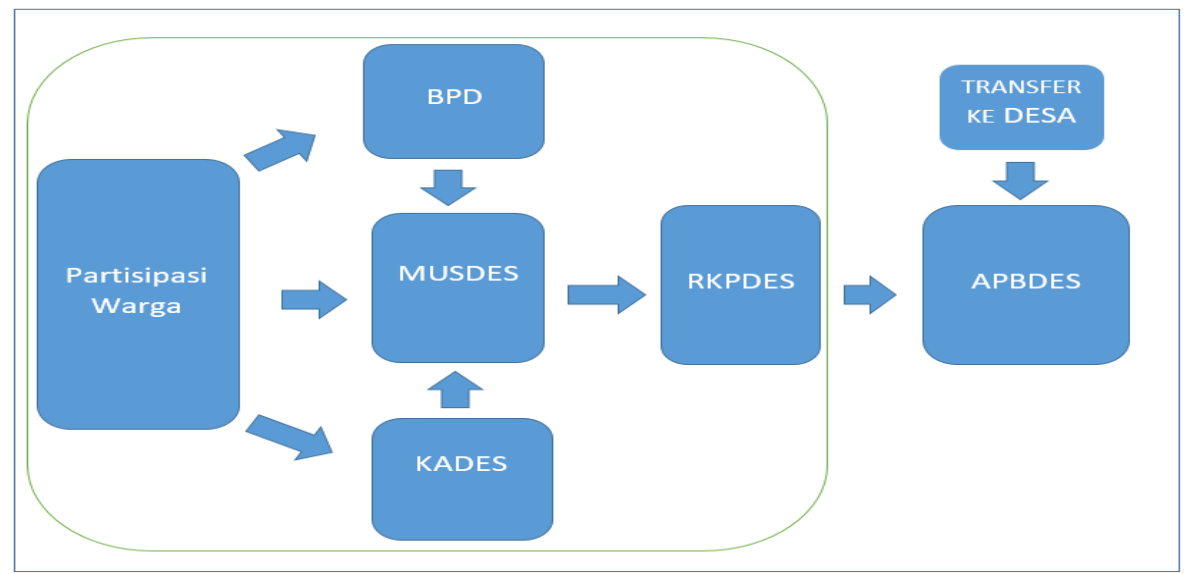

Sumber: diolah dari berbagai sumber 
Lampiran 4. Aspek partisipasi yang menjadi fokus penelitian

\begin{tabular}{|c|c|c|}
\hline \multirow{14}{*}{$\begin{array}{l}\text { PARTISIPASI } \\
\text { MASYARAKAT }\end{array}$} & ASPEK & INDIKATOR \\
\hline & \multirow{4}{*}{ Peran } & Pasif \\
\hline & & Tidak langsung (melalui tomas/toga/anggota BPD) \\
\hline & & $\begin{array}{l}\text { Terinformasi tapi tidak aktif (memperoleh informasi tentang } \\
\text { program/keg) }\end{array}$ \\
\hline & & Peran aktif (menanyakan informasi tentang APBDes) \\
\hline & \multirow{5}{*}{ Kesempatan } & Akses untuk ikut serta dalam rapat-rapat warga \\
\hline & & $\begin{array}{l}\text { Ada peluang masyarakat menyampaikan keluhan atau } \\
\text { keberatannya }\end{array}$ \\
\hline & & Ada kerjasama warga dengan pemerintah desa \\
\hline & & Ada keterlibatan dari awal \\
\hline & & Kebutuhan kelompok/masyarakat diperhatikan \\
\hline & \multirow{2}{*}{$\begin{array}{l}\text { Fungsi } \\
\text { Lembaga }\end{array}$} & $\begin{array}{l}\text { Bagaimana warga menyuarakan aspirasinya melalui anggota } \\
\text { BPD/tokoh masyarakat }\end{array}$ \\
\hline & & Apakah wakil warga (BPD/tokoh) bisa membawa aspirasi \\
\hline & \multirow{2}{*}{ Cara } & $\begin{array}{l}\text { Kebiasaan rapat-rapat umum dan rapat khusus menyangkut issue- } \\
\text { issue tertentu }\end{array}$ \\
\hline & & $\begin{array}{c}\text { Adanya kelompok/forum warga (jemaah pengajian, pkk, karang } \\
\text { taruna, petani, pedagang dan sejenisnya) }\end{array}$ \\
\hline
\end{tabular}

Sumber: Diolah dari Beckett \& King, The Challange to Improve Citizen Participation in Public Budgeting: A Discussion

\section{Lampiran 5. Bisnis Proses Perencanaan dan Penganggaran Model Perwakilan BPD}

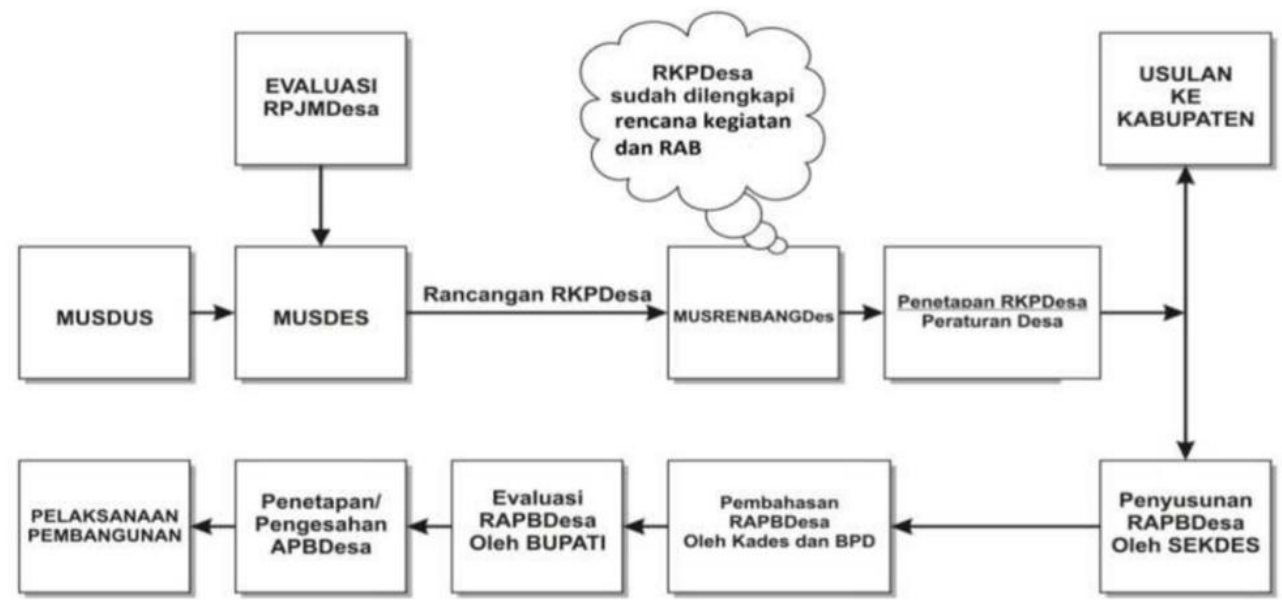

Sumber: Waskitojati, Handoyo, \& Wuryaningsih (2016) 


\section{ILUSTRASI TABEL}

\section{Lampiran 6. Tracking dan Mapping Sasaran per Bidang}

\begin{tabular}{|c|c|c|c|}
\hline NO & BIDANG & SASARAN & BENTUK KEGIATAN \\
\hline 1 & $\begin{array}{l}\text { Penyelenggaraan } \\
\text { Pemerintahan Desa }\end{array}$ & $\begin{array}{l}\text { 1. } \text { Meningkatkan kinerja } \\
\text { perangkat desa dan BPD } \\
\text { 2. Meningkatkan pelayanan } \\
\text { kepada masyarakat }\end{array}$ & $\begin{array}{ll}\text { 1. } & \text { Siltap Kades dan perangkat } \\
\text { 2. Tunjangan Kades dan Perangkat } \\
\text { 3. Tunjangan BPD } \\
\text { 4. Pembayaran honor linmas, kolektor PBB, penjaga kantor } \\
\text { desa } \\
\text { 5. Operasional kantor } \\
\text { 6. Insentif BPD dan lemkemas }\end{array}$ \\
\hline 2 & Pembangunan Desa & $\begin{array}{l}\text { 1. Memperlancar transportasi } \\
\text { antar lingkungan } \\
\text { 2. Meningkatkan kebersihan } \\
\text { lingkungan dan layanan } \\
\text { kesehatan }\end{array}$ & $\begin{array}{l}\text { 1. Pembangunan jalan desa } \\
\text { 2. Pemeliharaan jalan desa } \\
\text { 3. Pemeliharaan kebersihan jalan desa } \\
\text { 4. Pengadaan tanah untuk Posyandu } \\
\text { 5. Pemberantasan sarang nyamuk } \\
\end{array}$ \\
\hline 3 & $\begin{array}{l}\text { Pembinaan } \\
\text { Kemasyarakatan }\end{array}$ & $\begin{array}{l}\text { 1. Meningkatkan fungsi RT/RW } \\
\text { 2. Meningkatkan fungsi lembaga } \\
\text { kemasyarakatan }\end{array}$ & $\begin{array}{l}\text { 1. Pembinaan administrasi RT/RW. } \\
\text { 2. Pembinaan pemuda dan karang taruna. } \\
\text { 3. Pembinaan kader Posyandu dan PKK } \\
\text { 4. Bantuan keuangan untuk penyelenggaraan PHBI dan } \\
\text { PHBN. } \\
\text { 5. Bantuan santunan yatim piatu. } \\
\end{array}$ \\
\hline 4 & $\begin{array}{l}\text { Pemberdayaan } \\
\text { Masyarakat }\end{array}$ & $\begin{array}{l}\text { 1. } \\
\text { peningkatkan kualitas } \\
\text { 2. } \\
\text { Memberdayakan } \\
\text { perempuan melalui } \\
\text { peningkatan ketrampilan } \\
\text { ibu-ibu }\end{array}$ & $\begin{array}{l}\text { 1. Pelatihan poktan tanaman hias. } \\
\text { 2. Pelatihan tata boga } \\
\text { 3. Bantuan keuangan kepada kelompok tani dan kelompok } \\
\text { peternak. } \\
\text { 4. Bantuan kegiatan dan operasional TP PKK, } \\
\text { pemberdayaan perempuan dan penyaluran raskin ke RTS. }\end{array}$ \\
\hline 5 & Belanja Tak Terduga & Mengantisipasi kejadian bencana & 1. Antisipasi bencana alam (puting beliung dan kebakaran) \\
\hline
\end{tabular}

Lampiran 7. Sumber Pendapatan Desa Sasakpanjang Tahun 2015 - 2017

\begin{tabular}{|c|c|c|c|c|c|}
\hline No. & $\begin{array}{c}\text { Sumber } \\
\text { Pendapatan }\end{array}$ & Jenis & $2015(\mathrm{Rp})$ & 2016 (Rp) & 2017 (Rp) \\
\hline \multirow[t]{3}{*}{1.} & Pendapatan Asli & - Hasil Usaha & - & 45.000 .000 & - \\
\hline & Desa & - Gotong royong masyarakat & 85.000 .000 & 120.000 .000 & 49.500 .000 \\
\hline & & - Lain-lain pendapatan asli desa yang sah & 70.000 .000 & 85.000 .000 & - \\
\hline \multirow[t]{4}{*}{2.} & Pendapatan & - $\quad$ Dana Desa (DD) & 318.324 .116 & 727.441 .628 & 927.919 .262 \\
\hline & Transfer & - Alokasi Dana Desa & 593.232 .258 & 536.751 .929 & 534.813 .628 \\
\hline & & $\begin{array}{l}\text { - Bagian dari hasil pendapatan pajak dan } \\
\text { retribusi daerah }\end{array}$ & 209.008 .334 & 265.316 .825 & 341.723 .290 \\
\hline & & $\begin{array}{l}\text { - Bantuan keuangan pemerintah Provinsi } \\
\text { dan pemerintah Kabupaten }\end{array}$ & 730.110 .000 & 117.610 .000 & 770.220 .000 \\
\hline \multirow[t]{3}{*}{3.} & $\begin{array}{l}\text { Pendapatan Lain- } \\
\text { lain }\end{array}$ & $\begin{array}{l}\text { - Sumbangan pihak ke-3 yang tidak } \\
\text { mengikat }\end{array}$ & 20.000 .000 & 20.000 .000 & 6.617 .750 \\
\hline & & - Lain-lain pendapatan desa yang sah & 25.000 .000 & 43.000 .000 & 15.000 .000 \\
\hline & & TOTAL & 2.050 .674 .708 & 1.960 .120 .382 & 2.645 .793 .930 \\
\hline
\end{tabular}

Sumber: APBDes Sasakpanjang 2015 s.d. 2017

Lampiran 8. Belanja Desa Sasakpanjang Tahun 2015 s.d. 2017

\begin{tabular}{|c|c|c|c|c|c|}
\hline No. & Belanja APBDes & Jenis & $2015(\mathrm{Rp})$ & $2016(\mathrm{Rp})$ & $2017(\mathrm{Rp})$ \\
\hline \multirow[t]{10}{*}{1.} & Bidang Penyelenggaraan & - Penghasilan tetap dan tunjangan & 296.622 .000 & 268.375 .992 & 267.475 .260 \\
\hline & Pemerintah Desa & - Siltap Kades dan perangkat & 15.000 .000 & 15.000 .000 & 27.900 .000 \\
\hline & & $\begin{array}{l}\text { - Tambahan penghasilan pemerintah } \\
\text { desa }\end{array}$ & 21.000 .000 & 28.200 .000 & 21.600 .000 \\
\hline & & - Tunjangan kehormatan BPD & 12.600 .000 & 12.600 .000 & 15.600 .000 \\
\hline & & - Pembayaran honor & 28.852 .050 & 26.160 .123 & 43.678 .050 \\
\hline & & - Operasional perkantoran & & & \\
\hline & & - Insentif BPD dan Lembaga & 221.483 .263 & 237.700 .000 & 199.800 .000 \\
\hline & & Kemasyarakatan & & & \\
\hline & & - Belanja kendaraan & 150.000 .000 & - & - \\
\hline & & $\begin{array}{l}\text { - Pengembangan SID, pendataan dan } \\
\text { perencanaan pembangunan }\end{array}$ & - & - & 31.190 .000 \\
\hline 2. & Bidang Pelaksanaan & - Pembangunan RTLH & 250.000 .000 & 250.000 .000 & 300.000 .000 \\
\hline
\end{tabular}




\begin{tabular}{|c|c|c|c|c|c|}
\hline & Pembangunan Desa & - Pembangunan infrastruktur desa & 818.858 .000 & 844.271 .628 & 1.427 .920 .120 \\
\hline 3. & $\begin{array}{l}\text { Bidang Pembinaan } \\
\text { Kemasyarakatan }\end{array}$ & $\begin{array}{ll}\text { - } & \text { Pembinaan administrasi RT/RW } \\
\text { - } & \text { Pembinaan dan peningkatan kerja } \\
& \text { karang taruna } \\
\text { - } & \text { Pembinaan kader posyandu dan PKK } \\
\text { - } & \text { Bantuan keuangan }\end{array}$ & $\begin{array}{r}13.880 .000 \\
11.471 .000 \\
9.315 .000 \\
152.900 .000\end{array}$ & $\begin{array}{r}7.765 .000 \\
3.645 .000 \\
\\
6.515 .000 \\
219.400 .000\end{array}$ & $346.781 .658,00$ \\
\hline 4. & $\begin{array}{l}\text { Bidang Pemberdayaan } \\
\text { Masyarakat }\end{array}$ & $\begin{array}{ll}\text { - } & \text { Pelatihan Kelompok Tani Tanaman } \\
& \text { Hias } \\
\text { - } & \text { Pelatihan tata boga } \\
\text { - } & \text { Bantuan keuangan kelompok tani, } \\
& \text { UMKM }\end{array}$ & $\begin{array}{r}5.142 .500 \\
17.495 .287\end{array}$ & $\begin{array}{r}5.142 .500 \\
22.610 .000\end{array}$ & 2.832 .000 \\
\hline 5. & $\begin{array}{l}\text { Bidang Belanja Tak } \\
\text { Terduga }\end{array}$ & & 10.500 .000 & 4.735 .139 & \\
\hline & & TOTAL & 2.041 .974 .100 & 1.952 .120 .382 & 2.684 .177 .038 \\
\hline
\end{tabular}

Lampiran 9. Ringkasan Derajat Partisipasi Masyarakat Desa Sasakpanjang Menggunakan Tangga

\begin{tabular}{|c|c|c|c|}
\hline \multirow[b]{2}{*}{ NO } & & \multicolumn{2}{|l|}{ Partisipasi Arnstein } \\
\hline & TANGGA PARTISIPASI & HASIL YANG DIPEROLEH & $\begin{array}{c}\text { Derajat } \\
\text { Partisipasi }\end{array}$ \\
\hline 1 & $\begin{array}{l}\text { Manipulasi } \\
\text { Dalam bentuk ini biasanya partisipasi } \\
\text { dimaksudkan untuk mendidik atau } \\
\text { membangun dukungan publik dengan } \\
\text { memberi kesan bahwa pengambil keputusan } \\
\text { sudah bertindak partisipatif. Padahal } \\
\text { keputusan tidak diambil berdasarkan } \\
\text { masukan dari proses partisipasi. Dalam } \\
\text { bentuk ini biasanya yang digunakan adalah } \\
\text { pola pembinaan, humas (public relation) dan } \\
\text { lainnya. }\end{array}$ & $\begin{array}{l}\text { Informasi hanya bersifat umum dan normatif tentang } \\
\text { jadwal dan agenda musrenbangdes. } \\
\text { Tidak ada informasi yang dipublikasikan ke masyarakat } \\
\text { tentang rencana program/kegiatan. } \\
\text { Tahu-tahu ada pelaksanaan proyek oleh Pemdes. } \\
\text { Informasinya bersifat mendadak } \\
\text { Berapa APBDes yang dikelola tidak pernah diketahui oleh } \\
\text { warga. } \\
\text { BPD tidak mempunyai peran dalam menginformasikan } \\
\text { program/kegiatan kepada masyarakat } \\
\text { Masyarakat tinggal menerima kegiatan saja, dilibatkan } \\
\text { pada saat pelaksanaan kegiatan. }\end{array}$ & \\
\hline 2 & $\begin{array}{l}\text { Terapi } \\
\text { Terapi seharusnya berada di deretan paling } \\
\text { bawah partisipasi publik karena sifatnya } \\
\text { yang tidak jujur dan arogan. Contohnya } \\
\text { adalah bila ada suatu kesalahan pejabat } \\
\text { publik tertentu maka warga negara yang } \\
\text { terkena dampak dianjurkan untuk menemui } \\
\text { pihak yang bertanggung jawab terhadap } \\
\text { pengelolaan dan seolah-olah pengaduan } \\
\text { tersebut akan ditindaklanjuti. }\end{array}$ & $\begin{array}{l}\text { Dalam forum-forum kecil, misal kelompok-kelompok } \\
\text { pengajian di tingkat RT, rapat-rapat tingkat RT/RW } \\
\text { keterlibatan warga cukup tinggi, melalui forum-forum } \\
\text { inilah aspirasi warga didiskusikan. Kemudian aspirasi } \\
\text { disampaikan ke forum yang lebih tinggi. } \\
\text { Pada tingkat desa selain forum Musdes dan } \\
\text { Musrenbangdes hampir tidak ada. } \\
\text { Musyawarah dilakukan sekadar untuk memperoleh } \\
\text { persetujuan } \\
\text { Pertanyaan tentang APBDes di forum formal nyaris tidak } \\
\text { ada, baik dilakukan oleh BPD maupun warga. } \\
\text { Pemerintah desa terkesan menghindari pertanyaan yang } \\
\text { bernada mempersoalkan program/kegiatan, baik } \\
\text { menyangkut substansi maupun nilainya. (Dengan tidak } \\
\text { memberikan informasi secara terbuka kepada } \\
\text { masyarakat terhadap seluk beluk program/kegiatan yang } \\
\text { ditampung di dalam APBDes) }\end{array}$ & $\begin{array}{l}\text { Tidak ada } \\
\text { partisipasi }\end{array}$ \\
\hline 3 & $\begin{array}{l}\text { Penginformasian. } \\
\text { Dalam tahap ini biasanya sudah mulai } \\
\text { dilakukan pemberian informasi kepada } \\
\text { masyarakat mengenai hak, tanggung jawab } \\
\text { dan pilihan yang ada. Sayangnya sifatnya } \\
\text { masih satu arah hanya dari badan publik dan } \\
\text { belum diikuti dengan kesempatan tmtuk } \\
\text { mengasosiasikan pilihan. Pola ini juga } \\
\text { biasanya digunakan dalam bentuk } \\
\text { memberikan informasi yang tidak dalam } \\
\text { (sifatnya superfisial), tidak ramah terhadap } \\
\text { pertanyaan (discouraging questions) } \\
\text { ataupun memberikan jawaban yang tidak } \\
\text { benar terhadap suatu pertanyaan. }\end{array}$ & $\begin{array}{l}\text { Pra Musdes/Musrenbangdes menjadi } \text { media } \\
\text { menyampaikan informasi, tentang program/kegiatan } \\
\text { tetapi sifatnya monolog tidak dialog (partisipasi } \\
\text { masyarakat hanya formalitas saja). } \\
\text { Proses penentuan program/kegiatan tidak secara } \\
\text { terbuka }\end{array}$ & $\begin{array}{c}\text { Tokenism/ } \\
\text { Partisipasi } \\
\text { semu }\end{array}$ \\
\hline
\end{tabular}




\begin{tabular}{|c|c|c|}
\hline 4 & $\begin{array}{l}\text { Konsultasi } \\
\text { Dalam tahap ini sudah dilakukan konsultasi } \\
\text { dan dengar pendapat masyarakat terhadap } \\
\text { kebijakan yang diambil, sayangnya belum } \\
\text { diikuti dengan jaminan pendapat } \\
\text { masyarakat akan dipertimbangkan dalam } \\
\text { kebijakan yang akan dibuat. Dalam tahap ini } \\
\text { yang diperoleh masyarakat adalah "telah } \\
\text { berpartisipasi dalam proses partisipasi". } \\
\end{array}$ & $\begin{array}{l}\text { Ada forum MUSRENBANGDES/MUSDES, tetapi forum itu } \\
\text { terkesan hanya sekadar menggugurkan kewajiban. } \\
\text { BPD tidak bisa berperan sesuai fungsinya menampung } \\
\text { dan menyalurkan aspirasi. } \\
\text { Tidak pernah ada audiensi antara warga dengan BPD. } \\
\text { Masyarakat menyalurkan aspirasinya secara berjenjang, } \\
\text { melalui RT, RW kemudian ke Desa, tetapi tidak ada } \\
\text { mekanisme yang menjamin program/kegiatan yang } \\
\text { diusulkan tersebut masuk dalam APBDes atau tidak. }\end{array}$ \\
\hline 5 & $\begin{array}{l}\text { Peredaman (Placation) } \\
\text { Dalam tahap ini masyarakat sudah mulai } \\
\text { memiliki pengaruh terhadap kebijakan. } \\
\text { Namun sayangnya sifatnya masih belum } \\
\text { genuine. Keberhasilan partisipasi pada tahap } \\
\text { ini masih ditentukan oleh besarnya dan } \\
\text { solidnya kekuatan masyarakat untuk } \\
\text { menyampaikan kepentingannya. Dalam } \\
\text { tahap ini bentuk seperti keanggotaan } \\
\text { masyarakat dalam Dewan Kota misalnya } \\
\text { sudah dikenal. Namun sayangnya kadang- } \\
\text { kadang jumlahnya tidak signifikan sehingga } \\
\text { bila terjadi voting dalam pengambilan } \\
\text { keputusan mereka dapat dikalahkan dengan } \\
\text { mudah atau hanya sebagai penasehat, } \\
\text { sedangkan pengambil kebijakan tetap } \\
\text { berada di pihak pemegang kekuasaan. }\end{array}$ & $\begin{array}{l}\text { Pengisian anggota BPD melalui penunjukan oleh RW } \\
\text { karena lingkup perwakilannya di level RW } \\
\text { Pengisian jabatan pimpinan walaupun tidak secara } \\
\text { ekplisit diintervensi kepala desa, ada upaya secara } \\
\text { tersamar, agar yang terpilih menjadi unsur pimpinan BPD } \\
\text { adalah orang yang tidak berseberangan dengan kades. } \\
\text { BPD belum memiliki peran yang menentukan (pengaruh) } \\
\text { terhadap postur APBDes } \\
\text { Dalam pengambilan keputusan tidak diselenggarakan } \\
\text { melalui rapat resmi yang melibatkan anggota. }\end{array}$ \\
\hline 6 & $\begin{array}{l}\text { Kemitraan } \\
\text { Kekuasan dalam pengambilan keputusan } \\
\text { pada level ini sebenamya sudah terdistribusi } \\
\text { relative seimbang antara masyarakat desa } \\
\text { dengan pemerintah desa selaku pemegang } \\
\text { kekuasaan dan sudah terjadi kemitraan di } \\
\text { antara kedua belah pihak untuk } \\
\text { mendialogkan perencanaan dan } \\
\text { pengambilan keputusan bersama misalnya } \\
\text { melalui forum musyawarah perencanaan, } \\
\text { dewan kebijakan bersama, dan lainnya. } \\
\text { Namun sayang pada level ini, inisiatif dan } \\
\text { komitmen muncul setelah ada desakan } \\
\text { publikyang kuat untuk melaksanakan proses } \\
\text { yang partisipatif. Di level ini hal yang perlu } \\
\text { menjadip erhatian adalah: } \\
\text { 1.representasi dan pertanggungjawaban } \\
\text { perwakilan kelompok. } \\
\text { 2.kompetensi masyarakat untuk membekali } \\
\text { kelompoknya dengan ketrampilan yang } \\
\text { dibutuhkan seperti pemahaman terhadap } \\
\text { regulasi, dan kompetensi teknisi lainnya. }\end{array}$ & $\begin{array}{l}\text { Pada dasarnya masyarakat sudah secara alamiah } \\
\text { membentuk sendiri kelompok-kelompok untuk mereka } \\
\text { melakukan aktivitas sosial, seperti misalnya kelompok } \\
\text { pengajian RT, paguyuban dan sejenisnya. Tetapi cakupan } \\
\text { forum ini hanya dalam lingkup yang terbatas, sebatas } \\
\text { komunitasnya saja. Di forum ini masalah-masalah } \\
\text { bersama didiskusikan, kemudian dicarikan jalan } \\
\text { pemecahannya secara kolektif. } \\
\text { Kelompok-kelompok ini tidak banyak berharap adanya } \\
\text { bantuan dari pemerintah desa, kalaupun mengajukan } \\
\text { usulan dibantu syukur kalaupun tidak dibantu tidak } \\
\text { terlalu mempersoalkan, khususnya untuk warga di } \\
\text { lingkungan perumahan. Kelompok-kelompok yang ada } \\
\text { belum mempunyai posisi tawar terhadap pemerintah } \\
\text { desa, tidak mempunyai kekuatan untuk mendesakkan } \\
\text { kepentingannya/mempengaruhi kebijakan. }\end{array}$ \\
\hline 7 & $\begin{array}{l}\text { Delegasi kekuasaan } \\
\text { Pada tahap ini masyarakat sudah memiliki } \\
\text { kewenangan yang lebih besar dibanding } \\
\text { penyelenggaraan negara. Contohnya adalah } \\
\text { jumlah keanggotaan masyarakat yang lebih } \\
\text { besar dalam dewan kota ataupun adanyahak } \\
\text { veto bagi masyarakat dalam suatu dewan } \\
\text { perencanaan. Tantangannya lagi-lagi adalah } \\
\text { mewujudkan akuntabilitas dan menyediakan } \\
\text { sumberdaya yang memadai bagi kelompok } \\
\text { dimaksud }\end{array}$ & $\begin{array}{l}\text { Kerjasama masyarakat dan pemdes belum tampak nyata } \\
\text { dalam merumuskan program/kegiatan secara bersama- } \\
\text { sama. } \\
\text { Masyarakat belum tampak nyata terlibat dalam } \\
\text { perencanaan. Pada umumnya masyarakat tinggal } \\
\text { menerima hasil saja. } \\
\text { Masyarakat belum memiliki kapasitas teknis untuk } \\
\text { membuat need analysis perlu bantuan untuk bisa } \\
\begin{array}{l}\text { Masyarakat masih peran } \\
\text { mengorganisir diri dalam memperjuangkan } \\
\text { kepentingannya }\end{array}\end{array}$ \\
\hline 8 & $\begin{array}{l}\text { Kontrol warga (Citizen control) } \\
\text { Kontrol warga yang dimaksud adalah bukan } \\
\text { kewenangan tanpa kontrol (absolut power). } \\
\text { Pada tahap ini partisipasi sudah mencapai } \\
\text { tahap akhir dimana publik memiliki } \\
\text { kewenangan untuk memutuskan, } \\
\text { melaksanakan dan mengawasi pengelolaan } \\
\text { sumberdaya publik }\end{array}$ & $\begin{array}{l}\text { Masyarakat tidak memiliki control langsung terhadap } \\
\text { proses pengambilan keputusan. } \\
\text { Pemdes menerima dan menampung aspirasi masyarakat, } \\
\text { tetapi pemdes juga mempunyai pertimbangan sendiri } \\
\text { aspirasi mana yang layak untuk dieksekusi melalui } \\
\text { APBDes. }\end{array}$ \\
\hline
\end{tabular}

